\title{
İHRACATA YÖNELİK KALKINMA: GÜNEY KORE ÖRNEĞİ
}

\author{
EXPORT-ORIENTED DEVELOPMENT: AN EXAMPLE OF SOUTH KOREA
}

\author{
Hüseyin Tamer HAVA ${ }^{2}$
}

\section{$\ddot{O} \mathbf{z}$}

İhracata yönelik kalkınma stratejisi ve bununla birlikte meydana gelen yapısal değişimin gelişmekte olan ülkelerin kalkınmasında önemli bir rol oynayacağı son zamanlarda birçok ekonomistin yaptığı çalışmalarda ortaya koyduğu fikirlerle desteklenmektedir. Ancak başarıya ulaşan Güney Kore örneği açısından bu durum diğerlerine göre bazı farklılıklarla gerçekleşmiştir. İncelendiğinde bir zamanlar çok az doğal kaynaklara sahip, dış yardıma bağımlı ve borç içinde olan Güney Kore, Kore Harbi'nin üzerinden çok fazla zaman geçmeden 1960'lı yılların başlarından itibaren uygulanan politikalarla hızla sanayileşerek dikkat çekici bir ekonomik gelişme kaydetmiş ve kalkınmış bir ülke haline gelmiştir. Başlangıçta savaş sonrasında ithal ikamesine yönelik bir politika izleyen Güney Kore, 1960'lardan sonra kendine özgü gelenekleri ve yönetim yapısıyla ihracata yönelik kalkınma stratejisi modelini özdeşleştirerek uygulamaya koymuş, süreç içinde hızlı bir gelişim göstererek 1990'lı yıllardan sonra gerçekleştirdiği Ar-Ge yatırımlarıyla teknolojik gelişimini sağlayarak inovasyon dönemine girmiş ve ekonomik kalkınma başarısını sürdürülebilir hale getirmiştir.

Bu çalışmada, ihracata yönelik kalkınma stratejisi modelinin başarıyla uygulandığı ülkeler arasında her zaman ilk sırada gösterilen Güney Kore'nin bu başarısının ardında yatan nedenler tespit edilmeye ve bu süreçte karşılaşılan sorunlar ortaya konulmaya çalışılmıştır. Böylece bu ülkede yaşanan deneyimin ve bunun sonucunda ulaşılan başarının, her ülke farklı özelliklere sahip olsa bile, ekonomik kalkınmasını aynı modeli uygulayarak gerçekleştirmek isteyen diğer gelişmekte olan ülkeler için örnek olması amaçlanmıştır.

Anahtar Kelimeler: Güney Kore, İhracat, Kalkınma Stratejisi, İnovasyon, Uluslararası Ticaret.

\begin{abstract}
Export-oriented development strategy and the claim that the changes which come along with it will play an important role in the development of developing countries have been supported with the ideas that many economists have presented in their recent studies. However, for the successful South Korean example, this event has in some respects occurred differently from other countries. When examined, South Korea, initially with very little natural resources, dependent on foreign aid and in debt has rapidly industrialized with the policies implemented since the start of 1960s and experienced remarkable economic growth, rendering itself a developed country. In the beginning, South Korea followed an import substitution-oriented policy after the war. After the 1960s, South Korea has merged its unique traditions and administrative structure with the export-oriented development strategy model and has implemented it. South Korea has made rapid strides in the process, and after the 1990s, South Korea has entered the innovation period by providing its technological development with the $\mathrm{R} \& \mathrm{D}$ investments, and has made its economic development success sustainable.

This study attempts to determine the underlying reasons behind the success of South Korea, the country that is always ranked first among countries in which the export-oriented development strategy model has successfully been implemented and to put forth the issues that have been encountered during this process. Thus, the aim of this study is to set an example of South Korea's experience and its successful results for other developing countries, notwithstanding the different attributes of every country, which wish to economic develop via implementing the same model.
\end{abstract}

\footnotetext{
${ }^{1}$ Bu çalışma, 1993 yılında Anadolu Üniversitesi Sosyal Bilimler Enstitüsünde Prof.Dr. Hazım Nüvit OKTAY'ın danışmanlığında Hüseyin Tamer HAVA tarafından hazırlanan "Güney Kore'nin İhracata Yönelik Kalkınma Stratejisinin Değerlendirmesi” başlıklı yüksek lisans tezinden üretilmiştir.

${ }^{2}$ Dr.Öğr.Üyesi, Milli Savunma Üniversitesi, thava@msu.edu.tr, Orcid:0000-0002-5104-6688
}

Makale Türü: Araştırma Makalesi - Geliş Tarihi: 17.04.2020 - Kabul Tarihi: 10.09.2021

DOI:10.17755/esosder.721896 
Keywords: South Korea, Export, Development Strategy, Innovation, International Trade.

\section{GíRIŞ}

İhracata yönelik kalkınma stratejisinin gelişmekte olan ülkelerin kalkınmasında önemli bir rol oynayacağı birçok ekonomistin literatürde ortaya koyduğu fikirlerle desteklenmektedir. Ancak Güney Kore açısından bu durum diğerlerine göre bazı farklılıklarla gerçekleşmiştir. Önceden çok az doğal kaynaklara sahip, dış yardıma bağımlı, borç içinde ve bir tarım toplumu olan Güney Kore, savaş sonrasında radikal bir değişimle "ithal ikamesine" yönelik bir politika benimsemiştir. Başlangıçta ithal ikamesine yönelik bir politika izleyerek emekyoğun ürünlere ağırlık veren Güney Kore, 1960'lı yılların başlarından itibaren kendine özgü gelenekleri ve yönetim yapısıyla "ihracata yönelik kalkınma stratejisi modelini” özdeşleştirerek uygulamaya koymuştur. Özellikle 1970'ler ve sonrasında, devlet öncülügünde yürütülen kalkınma stratejisi ile hızlı sanayileşmenin de etkisiyle önemli ölçüde ekonomik gelişme kaydederek başarıya ulaşmış ve sanayileşmiş bir toplum haline gelmiştir.

1392 'de kurulan Yi (Joseon) Hanedanlığı (Peterson, 2009:77) ile geleneksel birlik ve beraberlik içinde yaşamış olan Kore, 19. yüzyıl sonlarında Japonya, Rusya ve Çin arasında yaşanan emperyalist yarışın odak noktası haline gelmiştir. Nihayet 1910 yılında Japonya Kore'yi ilhak ederek bir sömürge yönetimi kurmuştur (Ersun ve Sezer, 1991:3). Stratejik konumu nedeniyle yüzyıllar boyunca değişik boyutlarda savaşlara sahne olan Kore yarımadasının güneyinde yer alan Güney Kore, yarımadanın yüzölçümünün yaklaşık yüzde 45'ini kapsamakta ve sahip olduğu toprakların yüzde 70'i dağlık bölgeden oluşmakla birlikte nüfus yoğunluğu bakımından Asya'nın en kalabalık ülkelerinden biridir. (ANA BRITANNICA, 1989:517; TEIU, 1992:2).

$\mathrm{Bu}$ çalışmanın amac1, Güney Kore'nin 1960'lardan itibaren uyguladığı kalkınma stratejisini başarıya ulaştıran etkenlerin neler olduğunu tespit etmek ve bu süreçte hangi sorunlarla karşılaşıldığını ortaya koymaya çalışmaktır. Bu nedenle çalışma, farklı özelliklere sahip olsa bile Güney Kore'de yaşanan ihracata yönelik kalkınma deneyimi ve sonuçlarının farklı özelliklere sahip olsa bile diğer gelişmekte olan ülkelerin de aynı modeli uygulayarak kalkınmasını gerçekleştirebilmesi için dikkate alması gereken bir deneyim ve örneklem olması bakımından önem taşımaktadır. Araştırma, kalkınma stratejilerinin uygulanmaya başlandığı ve bu uygulamaların hızla başarıya ulaşılarak sürdürülebilir istikrarlı bir büyümenin yakalandığı süreci kapsayan 1960-2020 arası yıllar ile sınırlandırılmıştır.

İhracata yönelik kalkınma stratejisinin büyük bir başarıyla uygulandığı ülkeler arasında her zaman ilk örnek olarak gösterilen Güney Kore ekonomisi kapitalist piyasa ekonomisi olmakla birlikte, uygulamada bu stratejiyi uygulayan diğer ülkelere göre farklılıklar arz etmektedir. Ülkenin kalkınmasında devlet son derece önemli bir role sahip olup, kalkınma planlarına sadık kalınmaya çalışılarak birinci öncelik daima ekonomik gelişmenin sağlanmasında olmuştur. Ayrıca emek-yoğun sanayileşme ile sermaye-yoğun sanayileşme, ithal ikameci politika ile ihracatı artırma politikaları iç içe uygulanmıştır.

Çalışmanın amacı doğrultusunda öncelikle literatür taraması yapılmış ve teorik çerçeve verilmiştir. Sonra ki bölümde kalkınma stratejileri açısından ülke ekonomisinin tarihsel gelişimi incelenmiştir. Son olarak Güney Kore ekonomisinin hızlı gelişmesine neden olan etkenler ortaya konulmaya çalışılmış, ayrıca bu süreçte ortaya çıkan sorunlar incelenmiş ve ulaşılan sonuçlara dayanılarak yapılan değerlendirmelerle literatüre katkı sağlayacağ düşünülmüştür.

Tanıtıcı nitelikte bir araştırma olan bu çalışma, literatür taraması yöntemi ile gerçekleştirilmiştir. Bu kapsamda; bilimsel kitap, makale, rapor, ansiklopedi, gazete ve internet kaynakları, ayrıca Kore Bankası, Kore Kalkınma Bankası, Kore Exchange Bankası, 
Kore Ticaret Birliği'nin istatistik ve yıllık raporları taranarak belge ve veriler toplanmıştır. Bunlar araştırmanın amacına yönelik olarak okunmuş, değerlendirilmiş ve sistematik olarak düzenlenerek analiz edilmiş, bunlara dayanılarak ulaşılan sonuçlar ortaya konularak değerlendirmelerde bulunulmuştur.

\section{TEORIK ÇERÇEVE VE LITERATÜR TARAMASI}

Uluslararası ticarete yönelik benimsenen ekonomik yaklaşımlarda dönemsel olarak farklılıklar görülmüştür. Merkantilist dönemde ihracatın arttırılması ithalatın kısıtlanması benimsenmiş iken, Klasik İktisatçıların görüşü dış ticarette serbestleşmenin olması gerektiği yönünde olmuştur. Ancak bu görüş 1930'lu yıllardan sonra terk edilmiş, bunun yerine bireysel çıkarlardan ziyade toplumsal çıkarları savunan, eksik piyasa şartlarıyla, devlet müdahalesini de kapsayan anti-liberal yaklaşım önem kazanmıştır. Bu çerçevede gelişmekte olan ülkelerin sanayileşmesi için ithal ikameci politikaların uygulanmasına başlanmıştır. Keza bu durum 1929 Ekonomik Bunalımı'nın zorunlu bir sonucu olarak ortaya çıkmıştır. Bundan ötürü ülkelerin ihracatları olumsuz etkilenerek ödemeler dengesi açık vermeye başlamıştır. 1970'li yıllarda Neoklasik görüşe sahip iktisatçılar kalkınmaya yönelik olarak uygulanan ithal ikameci stratejiyi yoğun olarak eleştirmiştir. Bunun sonucunda 1980'li y1llarda alternatif olarak "dışa dönük sanayileşme stratejisi" önerilmiştir (Han ve Kaya, 2006:245). Bu bağlamda genel olarak ifade edilecek olursa, gelişmekte olan ülkeler kalkınmalarını gerçekleştirebilmek veya kalkınma seviyelerini yükseltebilmek için süreç içinde çeşitli ekonomik kalkınma stratejilerini uygulamaya koymuşlardır. Bunların başlıcalarını 'makroekonomik istikrarın sağlanması ve rekabet ortamının oluşturulması stratejisi', 'kalkınmada sürükleyici sektörlerin ve öncelikli bölgelerin belirlenmesi stratejisi' ile 'sanayileşme ve diş ticaret stratejisi' oluşturmaktadır. Bu kapsamda en çok kullanılanı ise 'sanayileşme ve diş ticaret stratejisi'dir. Keza bu strateji de 'ithal ikameci', 'ihracata (dışa) yönelik' ve 'karma sanayileşme' stratejileri olarak kendi içinde üç gruba ayrılmaktadır. İhracata yönelik kalkınma stratejisiyle kalkınmayı benimsemiş ülkelerin öncelikle sanayi malları ihracatını arttırması gerekir. Bu kapsamda uygulanması gereken başlıca politikalar 'döviz kuru ve devalüasyon politikası' ve 'ihracatı teşvik politikası'dır. Bununla beraber parakredi sisteminde reformların yapılması, enflasyonun üzerinde bir faiz politikasının uygulanması, dış ticaret rejiminde kademeli olarak liberalleştirme yapılması ve kotaların kaldırılması, gümrük vergilerinin minimum düzeye indirilmesi, konvertibiliteye geçilmesi, işletmelerde verimin arttırılmasına yönelik tedbirler ile kamunun ürettiği mallara gerçek fiyat uygulanması gibi tedbirlere de başvurulması gerekir.

İhracata yönelik kalkınma stratejisi II. Dünya Savaşı sonrasında Danimarka ve Norveç, 1950'li y1llarda Güney Avrupa ülkeleri ve Japonya, 1960'lı yıllarda Güney Kore, Singapur, Tayvan, hatta öncelikle Brezilya ve Arjantin olmak üzere çoğu Latin Amerika ülkesi, İsrail ve 1980 yılından itibaren de Türkiye tarafından uygulanmıştır (Çarıkçı, 1991:164). Başta Güney Kore olmak üzere bu ülkelerin gösterdiği yüksek kalkınma hızı diğer gelişmekte olan ülkeler için örnek olmuş ve bu ülkelerin çoğu ekonomik büyüme ve kalkınmada ihracata yönelik kalkınmayı temel strateji olarak benimsemiştir.

İthal ikameci kalkınma stratejilerinin başarısızlığından sonra kabul gören ihracata yönelik kalkınma stratejisinin kalkınmadaki başarısına yönelik tartışmalar da ortaya çıkmıştır. $\mathrm{Bu}$ bağlamda ihracata yönelik kalkınma stratejisi hipotezinin test edilmesi amacıyla birçok çalışma yapılmıştır. Yapılan çalışmaların birçoğunda ihracat ile ekonomik kalkınma arasındaki ilişkinin varlığı ortaya konulmuş, ancak uygulanan yöntemler ve hangi büyüklükte etkilediği konularında bir sonuca ulaşılması mümkün olmamıştır. Keza bu çalışmaların bir kısmında söz konusu hipotez desteklenmişken, bir kısım çalışmalarda ise hipotezin desteklenmediği bulgular ortaya konmuştur. 
Destekleyen araştırmalar: Balassa (1978)'nın 23 ülkeyi kapsayan 1960-1973 yıllarını için yaptığı çalışmasında ihracat ve ekonomik büyüme arasında pozitif yönde bir ilişki olduğu belirtilmiştir. Doğrudan Güney Kore için 1961-1986 yıllarını kapsayan Sengupta ve Espana (1994)'nın yaptığı çalışma ihracat odaklı sektörlerin Güney Kore'nin büyümesini önemli ölçüde etkilediği sonucuna ulaşılmıştır. 1990-1995 yılları için ihracata dayalı büyüme hipotezinin geçerliğini sınayan Nguyen (2016) çalışmasında hipotezin geçerliliği yönünde bir sonuca ulaşmıştır. 1957-1987 yıllarını kapsayan Japonya Kore ve Tayvan için ihracat ve ekonomik büyüme arasındaki nedensellik ilişkisini araştıran Sung-Shen ve arkadaşları (1990) da çift yönlü nedensellik ilişkisinin var olduğu sonucuna ulaşmışlardır. Gulzar ve Li (2018)'nin ARDL ve Granger nedensellik testini kullanarak Çin ve Pakistan örneğinde yaptığ1 çalışma sonucunda da ihracata dayalı büyüme hipotezinin doğruluğu sınanmıştır. Bu çerçevede Türkiye'de de ihracata yönelik kalkınma hipotezini destekleyen çalışmalar da mevcuttur. Taban ve Aktar (2008)'ın Türkiye için 1980-2007 yıllarını kapsayan hem EngleGranger hem de Johansen yaklaşımlarını kullandığı çalışmada ihracat büyümesi ile reel GSYİH büyümesi arasında uzun ve kısa vadeli çift yönlü nedensellik ilişkisini destekleyen kanıtların bulunduğu belirtilmiştir. Göçer ve Hepkarş1 (2013)'nın 1989-2013 y1lları için TodaYamamoto nedensellik analizini kullanarak Türkiye üzerine yaptığı çalışmada elde edilen sonuçlar ihracata dayalı ekonomik büyüme hipotezinin geçerli olduğunu ortaya koymuştur. Türkiye için ihracata dayalı büyüme hipotezinin Hiemstra ve Jones'un doğrusal olmayan nedensellik testlerini ve Panhenko'nun testini kullanarak Dura vd. (2017) tarafindan 19922014 yılları için yapılan incelemede hipotezin doğruluğuna yönelik güçlü kanıtlara ulaşılmıştır. Yine Türkiye için 1989-2016 yıllarını kapsayan ve ARDL sınır testi yapılarak Canbay (2020) tarafından yapılan çalışmada yüksek teknolojili ürünlerin ihracatındaki \%1'lik artışın büyümede \%0.44'lük artışa neden olduğu sonucuna ulaşılmıştır.

Desteklemeyen araştırmalar: Shan ve Sun (1998)'nun 1987-1996 dönemi için Çin özelinde yaptığı çalışmada ihracat ve reel sanayi üretimi arasında çift yönlü bir nedensellik ilişkisi bulunmuş, ancak ihracattan üretime tek yönlü bir nedensel sıralama olarak tanımlanan ihracata dayalı büyüme hipotezi ihracatın reel üretime pozitif katkısına rağmen reddedilmektedir. Hindistan için ihracata dayalı büyüme hipotezini Engle-Granger yaklaşımı kullanarak test eden Sharma ve Panagiotidis (2005) ihracatın büyümeye neden olduğu argümanına destek bulamamıştır. Teodora ve Marinela (2011) da Granger nedensellik testini kullanarak Romanya için yaptığı çalışmada ihracat ve büyüme arasındaki ilişkiyi önemsiz bulmuştur. Ağayev (2011)'in eski Sovyetler Birliği üyesi on iki geçiş ekonomileri için panel eşbütünleşme ve panel nedensellik yaklaşımlarını kullanarak yaptığı çalışmada elde edilen bulguların ihracat artışı ile büyüme arasında nedensellik ilişkisinin bulunmadığını ortaya koymuştur. Türkiye için yapılmış çalışmalardan olan Takım (2010)'ın 1975-2008 verilerini ve Granger nedensellik testini kullandığı araştırmada ihracattaki artışın büyümeyi etkilemediği sonucu elde edilmiştir.

\section{KALKINMA STRATEJILERİ AÇISINDAN GÜNEY KORE EKONOMISIININ TARİHSEL GELIŞSiMI}

Japon sömürgesi süresince Kore'nin ekonomik kaynakları insafsızca sömürülmüş, nüfusu hızla artmakta olan halk aşırı derecede yoksullaşmıştır. Bu dönemde Kore kayda değer bir endüstriye sahip olamamıştır. Ancak Güney Kore Cumhuriyeti kuruluşundan itibaren ekonomisini uluslararası pazarlarda rekabet edebilir hale getirebilmek için sistemli ve kararlı bir çaba içine girmiştir. Bunun için mevcut politikalar gözden geçirilerek diğer ülkelerden farklı politikalar uygulamaya konulmuş ve olumlu sonuçlara ulaşmıştır. Bu süreçte özellikle teknolojik olarak dünyayı yakalama çabası Güney Kore'yi özellikle 1980'lerden sonra kendi teknolojisini üretebilen bir ülke haline getirmiştir. Aşağıda ülke ekonomisinin tarihsel 
gelişimi kalkınma stratejileri açısından ele alınacak, temel ekonomik göstergelerin gelişimi incelenmeye çalışılacaktır.

Güney Kore'nin hızla gerçekleştirdiği sürdürülebilir kalkınmanın daha iyi anlaşılabilmesi için ülke ekonomisinin kalkınma stratejileri açısından tarihsel gelişimini beş ayrı döneme ayırarak incelemenin faydalı olacağı değerlendirilmektedir. Buradan hareketle ilk dönemin başlangıcı olarak, II. Dünya Savaşı'nın ve dolayısıyla Japon sömürgesinin bittiği 1945 yılı baz alınmıştır.

Kuruluş yıllarındaki ithal ikameci sanayileşme stratejisi dönemi (1945-1961): Japon işgali süresince Kore'de küçük ölçekli endüstri işletmeleri dışında kayda değer bir sanayileşme hareketi olmamıştır. 1945 yılında Japon sömürgesinden kurtulup bağımsızlığını kazandıktan sonra ülkede bazı ekonomik istikrar tedbirleri alınmıştır (Ersun ve Sezer, 1991:4). Ancak ülke 1945-1953 yılları arasında iç kargaşa ve bölünme sürecini yaşamıştır. Güney Kore bu bölünmeden bozuk bir ekonomiyle çıkmıştır. Doğal kaynakların çoğunluğu kuzey tarafında kalmış, altyapı tesisleri savaş nedeniyle büyük oranda tahrip olmuştur. Tekstil, metal ve kimya sanayileri büyük ölçüde çalışamaz duruma gelmiştir (TASAM, 2007:9-10). Ayrıca yetişmiş ve kalifiye insan gücü iç savaş nedeniyle büyük kayba uğramıştır.

Güney Kore'de ekonomik gelişme 1950'li yıllarda ithal ikameci sanayileşme stratejisiyle başlamıştır. Bu yıllarda yerli sanayiciler dışa karşı gümrük duvarlarıyla sıkı bir şekilde korunmuştur. Gümrük tarifeleri, kotalar, ithalat yasaklamaları, döviz kuru politikaları ve devletin almış olduğu diğer tedbirlerle hafif sanayi dalları kurulmuş bunların güçlendirilmesine çalışılmıştır.

Yine 1950'li yıllarda Güney Kore hükümeti, ekonomik istikrarı sağlamak ve ekonomik kaynakları genişletmek amacıyla IMF tarafından desteklenen bir istikrar programını uygulamaya koymuştur. Ancak uygulamaya konulan bu istikrar programı ekonominin dışa açılmasını hedeflemesine rağmen, 1960'lı yılların başına kadar dışa kapalı ithal ikameci sanayileşme stratejisine bağlı kalmıştır.

Bu dönemde, 1953-1961 yılları arasında GSMH'nın büyüme hızı yüzde 4, imalat sanayi büyüme hızı yüzde 10,5 olmuştur. İhracatın GSMH içindeki payı yüzde 1,1 iken ithalatın payı yüzde 10,6 olarak gerçekleşmiştir. Ayrıca bunlara ilaveten nüfus artış hızı da yüzde 3 olarak yüksek seviyede gerçekleşmiştir (Eski, 1989:15).

İthal ikameci sanayileşme stratejisinin uygulandığı bu dönemde ekonomi politikaları yetersiz kalmış, sosyo-ekonomik istikrarsızlıklara çözüm bulunamamış, nüfus artış hızı düşürülememiş, dolayısıyla ekonomik hedeflere ulaşmada başarı sağlanamamıştır. Bu nedenle Ekonomik Planlama Kurulu 1962 yılından itibaren Beş Yıllık Ekonomik Kalkınma Planları hazırlayarak uygulamaya koymuştur. Bu planların ekonomik amaçları ve temel politikaları Tablo 1'de görülmektedir.

Güney Kore'nin kalkınmasında büyük öneme sahip kalkınma planlarının uygulama süreçlerinde yaşanan belli başlı önemli gelişmeler aşağıda ele alınmıştır.

İhracata yönelik sanayileşme stratejisi dönemi (1962-1971): Güney Kore 1960’11 yıllarda çok az doğal kaynaklara sahip, adeta borç içinde yüzen, dış yardımlara bağımlı bir ülke durumundayken yeniden yapılanma sürecine girmiştir. $\mathrm{Bu}$ dönemde işsizlik ve gizli işsizlik son haddine gelmiş, ihracat ise yok denecek kadar azdır. Kişi başına GSMH ve yurtiçi tasarruflar ise oldukça düşüktür. Ayrıca sürekli açık veren bir dış ödemeler dengesine sahiptir.

Bu yıllarda Güney Kore'nin Kalkınma Planlarından ilkini (1962-1966) uygulamaya koymasıyla birlikte ülkede ticaret rejimi değiştirilmiş, dışa kapalı bir rejimden daha liberal bir 
rejime, düşük büyüme hızı ve fiyat istikrarını benimseyen stratejiden, hızlı büyümeye imkân tanıyan ihracata yönelik sanayileşme stratejisine geçilmiştir. Bu strateji tercih edilirken iki temel gerçek göz önünde bulundurulmuştur (Nas ve Oktar, 1986:4-5):

- Ülkenin tek ve en önemli kaynağı bol ve ucuz işgücü olduğundan sanayileşmenin emek-yoğun sanayi mamullerinin ihracatı ile sağlanması,

- Yurtiçi tasarrufların az, iç pazarın dar olması nedeniyle ithal ikameci sanayileşme yoluyla hızlı gelişme sağlanamayacağından ihracata yönelik sanayileşme yolunun seçilmesi ve uluslararası yabancı kaynaklardan yararlanarak hedefe daha kolay ulaşı1masi.

Tablo 1. Güney Kore'nin Plan Dönemlerinde Kalkınma Politikaları

\begin{tabular}{|c|c|c|}
\hline $\begin{array}{c}\text { BEŞ YILLIK } \\
\text { KALKINMA PLAN } \\
\text { DÖNEMLERİ }\end{array}$ & EKONOMIK AMAÇ & TEMEL POLİTIKALAR \\
\hline $\begin{array}{c}\text { 1. ve } 2 . \\
(1962-1971)\end{array}$ & $\begin{array}{l}\text { - Kendi kendine yetebilen } \\
\text { bir ekonomi oluşturmak } \\
\text { - Fakirlik kısı̈r döngüsünden } \\
\text { kurtulmak } \\
\text { - Ekonomide büyümeyi } \\
\text { sağlamak }\end{array}$ & $\begin{array}{l}\text { - İhracata yönelik büyüme } \\
\text { stratejisini uygulamak } \\
\text { - Hafif sanayiye önem vermek } \\
\text { ve ithal ikameci politikaları } \\
\text { uygulamak }\end{array}$ \\
\hline $\begin{array}{c}\text { 3. ve } 4 . \\
(1972-1981)\end{array}$ & $\begin{array}{l}\text { - Sanayi yapısını modernize } \\
\text { etmek } \\
\text { - Teknolojik alanda } \\
\text { gelişmek ve verimliliği } \\
\text { artırmak }\end{array}$ & $\begin{array}{l}\text { - Ağır ve Kimya Sanayiine } \\
\text { ağırlık vermek } \\
\text { - Sosyal sermaye } \\
\text { yatırımlarının genişletilmesi }\end{array}$ \\
\hline $\begin{array}{c}\text { 5. ve } 6 . \\
(1982-1991)\end{array}$ & $\begin{array}{l}\text { - Ekonominin rekabet } \\
\text { gücünü artırmak } \\
\text { - Gelişmiş bir ekonominin } \\
\text { temellerini oluşturmak }\end{array}$ & $\begin{array}{l}\text { - Dışa açık ekonomi ve istikrar } \\
\text { politikalarının uygulamaya } \\
\text { konulması }\end{array}$ \\
\hline $\begin{array}{c}7 . \\
1992-1996\end{array}$ & $\begin{array}{l}\text { - Mikro elektronik, yeni } \\
\text { malzemeler, sağlıkla ilgili } \\
\text { kimyasallar, } \\
\text { biyomühendislik, optik ve } \\
\text { havacılık gibi yüksek } \\
\text { teknoloji alanlarını } \\
\text { geliştirmek } \\
\text { - Güney Kore genelinde } \\
\text { sanayinin coğrafi dağılımını } \\
\text { daha iyi dengelemek için yedi } \\
\text { eyalet şehrinde yüksek } \\
\text { teknolojili üretim tesisleri } \\
\text { inşa etmek ve bunun için } \\
\text { hükümet ve sanayinin birlikte } \\
\text { çalıșması }\end{array}$ & $\begin{array}{l}\text { - Liberalleşmeye devam } \\
\text { ederek, devletin ekonomi } \\
\text { üzerindeki etkisini en aza } \\
\text { indirmek ve özel sektörü } \\
\text { güçlendirmek } \\
\text { İleri bir sanayi ekonomisi } \\
\text { oluşturmak } \\
\text { - Sosyal ve ekonomik eşitliği } \\
\text { sağlamak } \\
\text { - Sanayileşmekte olan bir } \\
\text { toplum olarak ihtiyaçlarını } \\
\text { karşılamak için eğitim ve } \\
\text { öğretim sistemi reformu yapmak }\end{array}$ \\
\hline
\end{tabular}

Kaynak: Hong, 2010:26-27; Savada \& Shaw, 1990. 
İhracata yönelik sanayileşme stratejisine geçilirken göz önüne alınan yukarıda belirtilen iki husus incelendiğinde, şimdiye kadar kapalı bir ekonomi politikası izlemiş, çok az doğal kaynaklara sahip bir ülkenin sadece emek-yoğun sanayi mallarında karşılaştırmalı üstünlüğe sahip olarak dişa yönelik bir kalkınma stratejisini benimsemesi oldukça dikkat çekicidir.

Yukarıda da bahsedildiği gibi Güney Kore'nin dışa yöneldiği Birinci Beş Yıllık Kalkınma Planı döneminde ulaşılması gereken hedefler aşağıda belirtilmiştir (Eski, 1989:18):

- Yeni çağdaş sanayilerin bir an önce kurulup geliştirilmesi,

- Kurulan bu sanayilerin ihtiyacı olan teknik donanımın, teknolojik bilginin ve sermayenin gelişmiş ülkelerden ülkeye aktarılması,

- Ülkede had safhaya ulaşmış olan işsizliğin azaltılması için emek-yoğun sanayi dallarının ihracata yöneltilmesi.

$\mathrm{Bu}$ hedeflere ulaşabilmek için hükümet piyasa mekanizmasının da yardımıyla eldeki mevcut iç ve dış kaynakları mobilize etmiştir. Özellikle yurtiçi tasarrufları hareketlendirebilmek için banka faiz oranlarını yükseltmiştir. Bunda başarı sağlanmış, bankalarda bulunan toplam tasarruf mevduatları önemli ölçüde artmıştır. Ülkede vergi yönetimi ve vergi sistemi değiştirilmiş, enflasyon ve bütçe açıkları kontrol altına alınmıştır. Kredi faiz oranları önemli ölçüde düşürülmüş, ithalat ve ihracat mevzuatları değiştirilerek gümrük işlemleri sadeleştirilmiş ve böylelikle ihracatçıların üretim için gerekli hammaddeleri kolayca ithal edebilmelerini sağlamıştır. Yabancı sermayeyi ülkeye çekebilmek için ise özendirici tedbirler alınmıştır (Kim, 2007:383-384).

İkinci Beş Yıllık Kalkınma Planı (1967-1971) döneminde de Birinci Beş Yıllık Kalkınma Planı hedefleri doğrultusunda hareket edilmiş, ihracata dönük olmak kaydıyla mevcut sanayi yapısı modernleştirilmeye çalışılmış, emek-yoğun hafif sanayi dallarına gereken önem verilmiş ve gelişmesi sağlanmıştır. Bunun paralelinde ihracata yönelik faaliyette bulunan endüstrileri destekleyebilmek için "İhracatı Geliştirme Kanunu" ve "Geçici Önlemler Kanunu" gibi bazı hukuksal düzenlemelere başvurulmuştur. Bu kapsamda yatırımlar planlamacılar tarafından elektronik, otomobil ve gemi inşası gibi stratejik sanayi gruplarına yönlendirilerek bu tür malların ithal edilmesini önlemeye çalışmış ve iç sanayinin güçlenmesi sağlanmıştır. Ekonomik Planlama Kurulu firma bazında ihracat hedefleri saptayarak bu hedefler tutturulamadığı durumda verilen teşvik kredilerini geri çekmiştir. İhracatta başarılı olan firmalara vergi indirimi ve üretimi yapılarak ihraç edilecek mallarda kullanmak için ithal edilen hammaddelerden alınan gümrüklerde indirim uygulanmıştır (TASAM, 2007:69; Yoo, 2008:47-48). Böylelikle 1962-1971 yılları arasında modern imalat ve ihracata yönelik yapısal dönüşüm çabaları Güney Kore'nin gelişmesinin öncü hareketleri olmuştur.

Nitekim GSMH 1962-1966 arasında yılda ortalama yüzde 7,9 artış göstermiş, 19671971 yıllarında ise bu oran yüzde 9,7 olarak gerçekleşmiştir. İhracatın GSMH içindeki payı aynı dönemler için sırasıyla yüzde 4,4 ve 9,5 olarak gerçekleşmiştir. İhracata yönelik sanayileşmenin belkemiğini oluşturan imalat sanayinin büyüme hızı ise yine aynı dönemler için sırasıyla yüzde 15,1 ve 21,8 olmuştur. Buna karşın 1962-1971 yılları arasında toptan eşya fiyatları endeksinin yıllık ortalama artış hızı yüzde 12 dolayında gerçekleşmiştir (Eski, 1989:9-11).

Ă̆ır sanayi ve kimya sanayinin gelişme dönemi (1972-1979): Cumhurbaşkanı Park Chong Hee, yönetiminin ikincisi olan bu dönemde ağır sanayi ve kimya sanayinin kurulması ve geliştirilmesi için yoğun bir çaba sarf etmiştir. Bunun için 1973 yılında bir deklarasyon yayınlayarak gemi yapımı, otomobil, endüstriyel makina üretimi, elektronik endüstrisi ve 
petrokimya endüstrileri gibi alanlar için yatırım yapılacağını açıklanmıştır. Bunların kurulabilmesi amacıyla oldukça çok miktarda sermayeye ihtiyaç vardı ve bunun için de devlet desteğine ihtiyaç duyulmaktaydı. Söz konusu endüstrilere yatırım yapacak olan chaebol'lere ${ }^{3}$ vergi indirimleriyle ayrıcalık tanındı. Yurtdışından gelen yardımlar Güney Kore Kalkınma Bankası tarafından düşük faizli ve uzun vadeli olarak chaebol'lere aktarıldı. Ayrıca 1975'ten 1977 yılına kadar banka kredilerinin yaklaşık yüzde 60 kadarı bu endüstrilerin kuruluşu ve geliştirilmesi için kullanıldı (Chung vd., 1997:30; Sridharan, 1996:69). Güney Kore hükümetinin bu uygulamalara geçmesinin temel nedenleri ve alınan tedbirler kısaca aşağıda sıralanmaya çalış1lmıştır (Kihwan, 1987:9-11):

- ABD 1971'de Güney Kore'deki askeri gücün üçte birini geri çekmiştir. Hükümet bu kararı ilerleyen zamanda ABD'nin ülkedeki askeri gücünün tamamını çekme planının başlangıcı şeklinde yorumlamış ve savunma sanayinin geliştirilmesi yönünde adım atmasına neden olmuştur.

- 1971 yılına kadar uluslararası para düzeninin belkemiği olan ve sabit kur sistemini benimseyen Bretton Woods sarsılmaya başlamış, uluslararası düzeyde korumacılık artmıştır. $\mathrm{Bu}$ nedenle Güney Kore, büyük oranda ihracata bağlı olan ekonomisinin gücünü koruyabilmek için yeni pazarlara girmiş, ihracatın bileşimini daha yüksek katma değerli sanayi mallarına kaydırmış ve savunma sanayini geliştirmeye çalışmıştır.

- Üçüncü Beş Yıllık Kalkınma Planı (1972-1976) çerçevesinde geliştirilmesi planlanan ağır sanayi, kimya, demir-çelik, petro-kimya, makine, elektronik ve gemi yapımı gibi sanayi dalları ülkenin faktör donanımına uygun olmadığından, geliştirilmesine çalışılmıştır.

- 1972-1973 yıllarında uluslararası düzeyde hammadde fiyatlarının artışı, 1973-1974 yıllarında petrol fiyatlarında meydana gelen hızlı tırmanışlar zaten dış kaynaklara bağlı olan ekonomiyi yıpratmıştır.

Yukarıda belirtilen nedenlerle hükümet bu dönem içinde ağır sanayi ve kimya sanayi yatırımlarına önem vermiştir. Böylelikle ihracata konu olan malların daha nitelikli olması ve savunma sanayi için gerekli malzemelerin yurtiçinden karşılanması hedeflenmiştir.

Bu kapsamda; Kore Makina ve Metal Enstitüsü, Kore Kimyasal Teknoloji Araştırma Enstitüsü, Elektronik ve Telekomünikasyon Araştırma Enstitüsü, Kore Enerji Araştırmaları Enstitüsü, Kore Standartlar ve Bilimsel Araştırma Enstitüsü ile Kore Okyanus Araştırmaları Enstitüsü gibi kuruluşlar yeni teknolojilerin endüstriye uyumunu sağlamak amacına yönelik olarak hükümet tarafından kuruldu. Bunların kurulmasındaki bir başka amaç ise, bu alanlara yatırım yapacak özel şirketlerin desteklenmesi olmuştur (Kim ve Nelson, 2000:273).

$\mathrm{Bu}$ dönemde hükümetin ekonomiye yön vermesiyle birlikte özel önem verilen tüm çalışmalar sonuç vermiş, ağır sanayi ve kimya sanayinin ürettiği ürünler toplam ihracatta 1972'de yüzde 25,3 pay alırken 1982'de bu oran yüzde 52,8'e çıkmıştır (Chung vd. 1997:30; Sridharan, 1996:69). Bunun paralelinde ihracatta ve GSMH'da da önemli oranlarda artış sağlanmıştır. GSMH 1972-1979 yılları arasında yıllık ortalama yüzde 9,1 artmıştır. İhracatın GSMH içindeki payı ise 1972'de yüzde 20,5 iken 1979'da yüzde 28,1'e yükselmiştir (KTA, 1992:3-7).

Dengeli büyüme dönemi (1979-1986): Güney Kore'nin bir önceki dönemde uyguladığ1 ağır sanayi ve kimya sanayisine yönelik politika 1970'lerin ikinci yarısından itibaren, özellikle 1980'lere doğru ekonomide bozulmaları beraberinde getirmiştir. Endüstriyel gelişimin bir gereği olarak vasıflı teknik eleman talebindeki artış, bunların reel ücretlerinde de 1975 'ten sonra ciddi artışlara yol açarak vasıflı ve vasıfsız işçiler arasında ücret farkları üç

\footnotetext{
${ }^{3}$ Chaebol: Güney Kore'de ailelerin egemen olduğu büyük ölçekli dev şirket/şirket gruplarına verilen addır.
} 
katına kadar çıkmıştır (Krueger, 1987:34). Ayrıca 1979 yılının sonunda Cumhurbaşkanı Park'ın bir suikast sonucu öldürülmesi ülkede siyasal istikrarsızlığı artırmıştır. Bu nedenlerle ekonomide yaklaşık yirmi yıldır süren hızlı gelişme süreci ilk kez gerilemiştir (KTA, 1992:36). Nitekim Tablo 2 de görüleceği üzere, 1980 yılında GSMH negatif yönde bir büyüme göstererek yüzde -1,6 olarak gerçekleşmiştir. Enflasyon ise tüketici fiyatlarıyla yüzde 28,7'ye yükselmiştir.

Önceki dönemde bozulmaya başlayan ekonominin toplanarak yeniden istenilen düzeye gelmesini sağlayabilmek için hükümet, 17 Nisan 1979 tarihinde "Kapsamlı İstikrar Programı"nı yürürlüğe koymuştur. Bu program dört temel bölümden oluşmuştur. 1) Sıkı para ve maliye politikası, 2) Fiyat istikrarı, 3) Kısa dönem için ağır sanayi ve kimya sanayi yatırımları dağılımındaki dengenin sağlanması, 4) Ekonomik liberalizasyona geçişin uzun dönem içinde gerçekleştirilmesi (Krueger, 1987:35). Fakat istikrar programı, 1980 yılında Chon Du Hwan'ın Cumhurbaşkanı oluşuna kadar dünya petrol krizi, 1980 yılındaki aşırı soğuk ve don nedeniyle tarımsal üretimin düşmesi ve Cumhurbaşkanı Park'ın bir suikast sonucu öldürülmesi gibi nedenlerle etkili olarak uygulanamamıştır.

Eski bir general olan Chon Du Hwan göreve geldikten sonra "Kapsamlı İstikrar Politikası" doğrultusunda bir dizi tedbirleri hemen uygulamaya koymuştur. Bunlardan en önemlileri; fiyat dengesinin sağlanması, piyasanın liberalleştirilmesi, ekonomik büyümede dengenin sağlanması ve ithalatta kotaların kaldırılmasıdır. Bunlardan başka bankaların özelleştirilmesi, yeni finansal kurumların tesis edilmesi ve faiz oranlarının artırılması gibi politikalar hayata geçirildi. Ağır sanayi ve kimya sanayine verilen krediler donduruldu. Chaeboller'in kartelleşmesine ve fiyat sabitlemesine engel olmak için çeşitli tedbirlere başvuruldu. Ar-Ge faaliyetlerinin ve teknolojik projelerin teşvik edilmesi için düzenlemeler yapıld1 (Ungson vd., 1997:52-53).

Ayrıca aşırı korumacılığın kaldırılmasını hedefleyen hükümet dış ticarette giderek artan oranda liberalizasyona gitmiştir. 1983 yılında ithalattaki liberalizasyon oranı yüzde 80 iken (Arıkan, 1986:26) 1984'de yüzde 84,8, 1985'de yüzde 87,7 ve 1986 'da ise yüzde 91,5'e yükselmiştir. Bu doğrultuda gümrük tarife oranları da 1983 yılında yüzde 22,6'ya ve 1986'da yüzde 18,7'ye indirilerek kademeli olarak aşağı çekilmiştir (İGEME, 1990:7-9). Bunların sonucu olarak Tablo 2'de görüleceği üzere dış ticaret dengesi açığı toparlanmaya başlamış ve bu durum sonraki yıllarda da devam etmiştir.

Bir diğer düzenleme de yabancı sermayeyi teşvik politikasında yapılmıştır. Uygulamaya konulan "Yabancı Sermaye Kanunu" çerçevesinde yabancı yatırımlar için yüzde yüzlük vergi ertelemesine imkân sağlanmıştır. Hükümet, serbest yabancı yatırımcıların belirtildiği "Positive List" uygulamasından, yabancı yatırımların yasaklandığı veya kısıtlandığı endüstriyel alanları kapsayan "Negative List" adlı listelemeye geçmiştir.

Böylelikle listede belirtilmeyen endüstrilere yapılacak olan yatırımlar için Maliye Bakanlığg'ndan izin alma zorunluluğu kaldırılmıştır. Bunun bir sonucu olarak 999 endüstriyel alanın 762'si yabancı yatırımlara açılmış, imalat sanayinin ise yüzde 92,5'i serbestleşmiştir (İGEME, 1990:7-9). Negative List uygulamasıyla yabancı yatırımcıların ülkeye çekilmesinde başarıya ulaşılmıştır.

$\mathrm{Bu}$ dönem Tablo 2'den de faydalanarak genel olarak değerlendirilecek olursa; "Kapsamlı İstikrar Politikası" kapsamında alınan tedbirler ve uygulamaların olumlu sonuçları 1980'li yılların ortalarında görülmeye başlamıştır. Enflasyon oranı önemli ölçüde gerilemiş, büyüme oranı ise 1980 yılında negatif seviyede iken sonraki y1llarda yükselme eğilimine girmiştir. Yine aynı yıllardan itibaren yurtiçi tasarrufların oranları da artmıştır. Belirtmek gerekir ki, Güney Kore ekonomisindeki bu istikrarlı gelişme ülkenin ihracat pazarını genişleterek dış ticarette yeniden rekabet gücünü kazanmasına neden olmuştur. 
Altıncı Beş Yıllık Plan dönemi (1987-1991): Temel özellikleri ve uygulama süreçleri Tablo 1'den incelendiğinde yine önceki plan döneminde olduğu gibi bu dönemde de ekonominin rekabet gücünün artırılması ve gelişmiş bir ekonominin temellerinin oluşturulması amacıyla dışa açık ekonomi ve istikrar politikalarının uygulanması hedeflenmiştir.

$\mathrm{Bu}$ kapsamda planın öncelikli amaçları sosyal refah, dengeli büyüme ve ithalatın liberalizasyonunun hızlandırılması olmuştur. Ayrıca bu dönemde önceden daha çok önem verilmiş olan büyük holdingler ve Chaebol'lerin yerine küçük ve orta boy işletmelere devletin sağladığı doğrudan destekler artırılmıştır (TMMOB, 2007:75). İthalatın liberalizasyonu kapsamında serbest dış ticaret ilkelerine sadık kalmak koşuluyla ithalat işlemlerinin kolaylaştırılması da diğer bir adım olmuştur.

Yedinci Beş Ylllık Plan dönemi (1992-1996): Bu plan dönemiyle birlikte Güney Kore Ekonomisi olgunlaşma dönemine girmiştir. 1989'da hazırlanan Beş Yıllık Ekonomik ve Sosyal Kalkınma Planı'nın temel amaçları; mikro elektronik, yeni malzemeler, sağlıkla ilgili kimyasallar, biyomühendislik, optik ve havacılık gibi yüksek teknoloji alanlarının geliştirmesi olmuştur. Ayrıca Güney Kore genelinde sanayinin coğrafi dağılımını daha iyi dengeleyebilmek için yedi eyalet şehrinde yüksek teknolojili üretim tesislerinin inşa edilmesi, bunun gerçekleştirilebilmesi için de hükümet ve sanayinin birlikte çalışması amaçlanmıştır. Bunların gerçekleştirilebilmesi için ileri bir sanayi ekonomisinin oluşturulması, sosyal ve ekonomik eşitliğin sağlaması, sanayileşmekte olan bir toplum olarak ihtiyaçların karşılanabilmesi için eğitim ve öğretim sistemi reformunun yapılması gibi temel politikaların uygulanmaya konulması hedeflenmiştir (Savada \& Shaw, 1990).

1996 Sonrası: Kalkınma planları Güney Kore'nin gelişmesinde çok önemli bir role sahiptir. Ekonomik Planlama Kurulu'nun Beşer Y1llık olarak hazırladığı Ekonomik Kalkınma Planları 1996 yılına kadar başarıyla uygulanmıştır.

Asya Krizinin ortaya çıkmasıyla birlikte önemli sıkıntıyla karşılaşan Güney Kore 1997'de beş yıllık kalkınma planı uygulamalarına son vermiş ve 1998 yılından itibaren kısa vadeli programlar uygulamaya başlamıştır. Yeni Ekonomik Programla öncelikle krizden kurtularak yeniden eski büyüme hızına ulaşılması amaçlanmıştır (TMMOB, 2007:72-73).

Krize bağlı olarak tüketim ve yatırım talebinin düşmesinin sonucu olarak ekonomide üretim kapasitesi oldukça düşmüştür. Güney Kore krizden çıkış için ihracatın artırılmasını hedeflemiştir. Ayrıca 1998 yılı ve sonrasında uygulanmaya başlanan sıkı mali politika ve reformların sonucunda krizin etkileri azalmış ve ekonomi toparlanarak yeniden büyümeye başladı (TMMOB, 2007:73-74). 2000'li yıllardan sonraki büyüme hızı önceki yıllara göre daha yavaş olsa da ülke sadece birkaç yıl içinde borçlarından kurtulmuş, ancak muazzam bir ekonomik ve politik etkiye sahip büyük holdinglerin hakimiyetinden kurtulamamıştır. Yine de birçok zorluklara rağmen özellikle teknolojik yenilik konusunda oldukça önemli bir ülke haline gelmiş ve günümüzde küresel ticarete yön verici bir role sahip olmuştur (Seth, 2017).

\section{GÜNEY KORE'NIN İHRACATA YÖNELIK KALKINMA STRATEJISINIIN DEĞERLENDİRILMESİ}

Güney Kore'yi coğrafi, demografik, tarihsel, idari durum ve kalkınma stratejileri açısından ülke ekonomisinin tarihsel gelişimi inceledikten sonra Güney Kore ekonomisinin hızlı gelişmesine neden olan etkenleri ve bu süreçte karşılaşılan başlıca sorunları ortaya koymak konunun daha iyi anlaşılmasını sağlayacaktır. Her ne kadar Güney Kore'nin hızla gelişmesinin arkasında çok sayıda parametreler olsa da bunlardan en önemlileri aşağıda açıklanmaya çalışılacaktır. 


\subsection{Güney Kore Ekonomisinin Hızlı Gelișmesine Neden Olan Etkenler}

4.1.1. Güney Kore halkının sosyo-kültürel yapısı ve Japon sömürgesinin etkileri Güney Kore ekonomisinin gelişmesinde halkın mevcut geleneksel yapıs1, ahlak ve değer sisteminin oluşturduğu sosyo-kültürel yapı ile 1910 yılında başlayıp 1945 yılında sona eren Japon sömürgesinin bu süreçte ülke üzerindeki etki ve bıraktığı kurumlar önemli role sahip olan faktörlerdendir.

Tablo 2. Güney Kore’nin Temel Ekonomik Göstergeleri (1960-2020)

\begin{tabular}{|c|c|c|c|c|c|c|c|c|c|}
\hline$\underset{\bar{\Xi}}{\stackrel{\Xi}{\Xi}}$ & 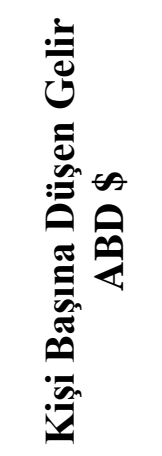 & 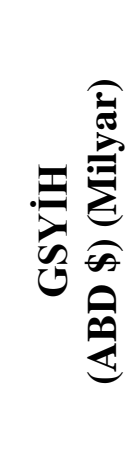 & 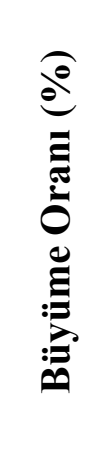 & 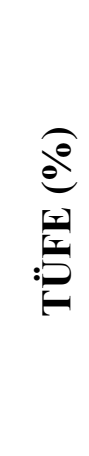 & 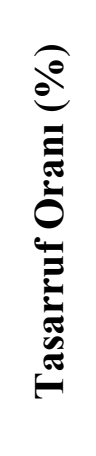 & 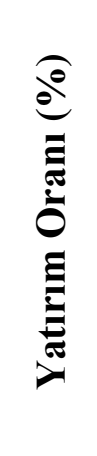 & 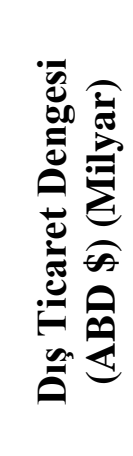 & 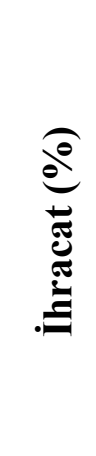 & 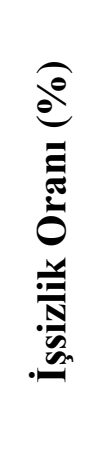 \\
\hline 1960 & 158.2 & 3.9 & 2,3 & 8,0 & 0,6 & 9,7 & -370 & 2,6 & $6,4^{*}$ \\
\hline 1970 & 279.3 & 9.0 & 10,1 & 16,0 & 16,4 & 25,6 & -872 & 11,4 & 4,5 \\
\hline 1980 & $1,715.4$ & 65.4 & $-1,6$ & 28,7 & 25,4 & 34,1 & $-6,896$ & 28,4 & 5,2 \\
\hline 1990 & $6,610.0$ & 283.3 & 9,9 & 8,6 & 38,8 & 39,5 & $-2,804$ & 25,0 & 2,5 \\
\hline 2000 & $12,257.0$ & 576.1 & 9,1 & 2,3 & 34,6 & 33,1 & 10,181 & 33,9 & 4,1 \\
\hline 2010 & $23,087.2$ & $1,144.0$ & 6,8 & 2,9 & 35,4 & 32,6 & 27,951 & 47,1 & 3,3 \\
\hline 2020 & $31,489.1$ & $1,630.5$ & $-0,9$ & 0,5 & 35,4 & 31,7 & 46,409 & 36,9 & 3,9 \\
\hline
\end{tabular}

*1959 yılı verisi kullanılmıştır.

Kaynak: IMF (2021); World Bank; Korean Statistical Information Services (KOSIS); Bank of Korea.

Güney Kore inançlar açısından heterojen bir yapıya sahip olup, ülkede dünyanın başlıca dinleri etkin durumdadır. Her kişi inandığı dinde özgürdür ve bu anayasa ile tam olarak güvenceye alınmıştır. Ülkede bilinen en eski dinler Şamanizm, Budizm ve Konfüçyanizm ${ }^{4}$ 'dir. Bunlar ülkenin kültürel gelişiminin temel taşları olarak halkın düşünce ve

\footnotetext{
${ }^{4}$ Konfüçyanizm, modern toplumda meydana gelen sorunlara çare bulabilen öğrenme saygısını yetiştirmeye ve ahlak anlayışına inanmaktadır. Çocuklar, öğretilen inanç ve davranış biçimiyle yetişkin birer insan haline geldiklerinde, hiyerarşik düşünmeye yönelmiş bir şekil alırlar. Bu şekilde düşünmeye yönlendirilen insanlar yaşamın her alanındaki ilişkilerinde daima yukarıdan aşağıya doğru düşünerek hareketlerini düzenlemektedir (Kazgan, 1985: 127). Konfüçyüs düşüncesine sahip her kişi için çalışmak insan için bir değer ve yaşamın temel
} 
davranışlarını önemli ölçüde etkilemiştir. Yakın geçmişte Hristiyanlık dini de tanınmaya başlamış ve hızla yayılmıştır. Ayrıca söz konusu geleneksel dinlerin karışımı olarak nitelendirilebilecek küçük çaplı değişik dinler de halkı etkilemiştir. 1989 yılında halkın yüzde 40,6'sının inandığı din bellidir. Bunların çoğunluğu Budizm'e inanmakta olup oran yüzde 46,9'dur. Bunu sirasiyla yüzde 37,7 ile Protestanlar, yüzde 10,8 ile Katolikler, yüzde 2,8 ile Konfüçyanistler ve yüzde 1,8 'lik bir oranla diğer dinlere inananlar izlemektedir (ANA BRITANNICA, 1989:136,520).

Doğu Asya ülkelerinin ortak özelliği olduğu kabul edilen ve Konfüçyanist yaşam tarzının karakteristiği olarak kabul edilen sadakat (Cong), baş eğme (Şiao) ve buna benzer davranış tarzları (Sönmez, 2001:75) Güney Kore için de söz konusudur. Bu yaşam tarzının Batı'nın bireyci ideolojisinden farklı olarak kolektif bir bilinçle kendini ulusal amaçlara adadığı ileri sürülerek (Shutt, 2004:206) Güney Kore'nin kalkınmasında bunun önemine vurgu yapilmaktadir.

İnanç açısından bir diğer önemli husus ise, Weber'in (1985:11-25) kültürel yapı ile ekonomik kalkınma arasında ilişki kurarak Batı'daki kapitalist gelişmeyi Protestan ahlakına dayandırması tezinin England ve Misumi (1986:399-416) tarafından desteklenerek bunun Doğu Asya ülkeleri için de geçerli olduğunun ifade edilmesidir.

Diğer taraftan öğrenmeye büyük önem veren Güney Kore'de eğitimle insanın şekillendirilmesi esas tutulmaktadır. Bunun bir sonucu olarak halk başarabileceğine inandığ 1 her türlü olaya kendini motive ederek o olayı mutlaka çözüme kavuşturur. Ayrıca Güney Kore halkı diğer toplumlarda pek mümkün olarak görülmeyen, inanılmaz derecede zor koşullara katlanma direncine ve çelişkilerle yaşama özelliğine sahiptir. Bir başka özellikleri ise çok görüşlülükten ziyade tekseslilik, itaat ve uyumlu davranış ilkelerinin ön planda olmasıdır. $\mathrm{Bu}$ doğrultuda halk yükümlülüklerini ve ödevlerini bireysel haklarından ön planda tutarak "ben" yerine "biz" düşüncesine sahiptir (Eski, 1989:50-51). Buradan öğrenmenin ve eğitimin ekonomik ve sosyal yaşam standartlarının yükseltilmesine önemli katkısının olduğu çıkarımında bulunmak yanlış olmayacaktır.

1910-1945 yılları arasında Japon sömürgesi altında yaşamış Güney Kore'de bağımsızlığını kazandıktan sonra üzerinden yıllar geçmiş olsa bile Japon kültürünün izlerinin hâkim olduğu hala görülmektedir. Vogel (1991) "The Four Little Dragons: The Spread of Industrialization in East Asia" adlı kitabında bunu Güney Kore'nin hizlı ekonomik büyümesinin nedenlerinden biri olarak belirtmiş, aynı coğrafyada benzer özellikleri bulunan ve daha önceden sanayileşmeye başlayan Japonya örneğinden esinlendiğini ifade etmiştir. Ayrıca hızlı büyümenin yaşandığı yıllarda haftalık ortalama 60 saatlik çalışma süreleriyle disiplinli çalışan işgücünün varlığına da dikkat çekmiştir. Nitekim 1990'lara gelindiğinde bile diğer sanayileşmekte olan veya sanayileşmiş ülkelere göre hafta sonu tatilinin yalnızca bir gün, haftalık ortalama çalışma saatinin 55 saat olması bunun bir göstergesi olarak karşımıza çıkmaktadır (Öz, 2008:36).

Sömürge dönemi oldukça ağır koşullarda geçmiş, ancak bu koşullar Güney Kore'nin gelişmesi için oldukça elverişli bir ortam oluşturmuştur. Sömürgecilik sona erdiğinde miras olarak birçok altyapı tesisleri, kurumları ile çok sayıda zengin girişimci bir topluluk kalmıştır (Kazgan, 1985:127). Gerçekten Japon girişimcilerin sahip olduğu sermaye miktarlarının çokluğu Güney Kore ekonomisinin hızlı gelişmesinde altyapıyı oluşturmuş, aynı zamanda sanayi alanındaki yönetici, mühendis ve teknikerlerle desteklenmiştir. Bunun paralelinde söz

gereğidir. Bu düşünce sistemi geçmişe önem verirken geleceğe daha büyük önem vermektedir. Bu düşüncenin bir sonucu olarak tasarruf yapma eğilimleri de oldukça güçlüdür. 
konusu dönemde gerek iş dünyası gerek teknoloji ve gerekse ticari alanda önemli tecrübeler edinilmiştir.

\subsubsection{Amerika Birleşik Devletleri (ABD)'nin etkileri}

Güney Kore ekonomisinin hızlı gelişmesine neden olan etmenlerin en önemlilerinden birisi de ABD’nin göz ardı edilemeyecek etkileridir.

İkinci Dünya Savaşı'nda yenilen Japonlar 15 Ağustos 1945 tarihinde ülkeden çekilmeden önce Sovyetler Birliği'nin Kore yarımadasını 38. Paralel'e kadar işgal etmesine karşılık olarak ABD'de 8 Eylül 1945 tarihinde Kore'nin güneyini işgal etti. Böylece yarımada müttefik iki ülke arasında fiilen paylaşıldı (Karaosmanoğlu, 2013:31). ABD’nin bu girişimi Sovyetler Birliği'nin nüfuz alanını artırmasını ve komünizmin yayılmasını önlemeyi hedefliyordu (Lie, 1998:24). İkinci Dünya Savaşı'nın sona ermesiyle iki ülke arasında ittifak bozulmuş ve Kore bu iki blok arasında rekabete konu olmuştur. Ülkenin fiilen ikiye bölünmüşlügü 1948 yılında Güney Kore Cumhuriyeti ve Kuzey Kore Halk Cumhuriyeti olarak resmiyete kavuşmuş oldu (Çakmak, 2015:181).

Bundan sonraki yıllarda yaşanan ve üç yıl süren Kore Savaşı'nın etkisiyle büyük tahribat yaşayan Güney Kore giderek fakirleşmiş, dış yardımlara muhtaç olmuştur. ABD'nin İkinci Dünya Savaşı sonrasında dünyadaki egemenliğini sürdürme isteği, siyasi ve ekonomik ilgisini az gelişmiş ülkelere yöneltmesine neden olmuştur. Bu çerçevede Güney Kore'nin savaşta aldığı yaraların sarılması uluslararası kuruluşlar tarafindan olduğu kadar ABD tarafından da yapılan yardımlarla da sağlanmaya çalışılmıştır.

Savaştan sonra yaşanan buhran dönemi ABD ve Birleşmiş Milletler Örgütü'nün çeşitli yardım ve destekleriyle atlatılmaya çalışılmış, çöken ekonominin ayağa kaldırılarak yeniden kurulmasında ABD'nin büyük payı olmuştur. Bunlardan en önemlileri; mali yardım, teknik eleman desteği, sanayide ve tarımda yeni teknolojilerin uygulamaya konulmaya çalışılmasıdır. Bunun paralelinde "Amerikan Sistemi" kamu yönetiminde, işletme yönetiminde, sanayi, tarım, ekonomik ve sosyal yaşamda da etkisini göstermiştir (Aslan ve Taner, 2016:31). Nahn (1998:222-228) tarafından Güney Kore'nin bu kapsamda 1961 yılına kadar aldığı dış yardımların 1,9 milyar dolar ABD'den, 150 milyar dolar BM'den olduğu ifade edilmektedir.

\subsection{3. İhracata yönelik kalkınma stratejisine geçiş}

Rhee yönetiminin 1960 yılında şiddetli öğrenci protestoları ile sona ermesiyle iktidara gelen Chang Myon hükümeti de ülkeyi bir yıl gibi kısa bir süre yönetebildi. Sonrasında askeri bir darbe sonucu Tümgeneral Park Chung Hee iktidarı ele geçirdi. Yıllarca iktidarda kalacak olan Park'ın üzerinde durduğu iki ana konu vardı. Birincisi ihracatı teşvik amacıyla yabancı yardımları girişimci firmalara aktarmak, ikincisi ise ağır sanayi hamlesini başlatmaktı (Kim, 1997:99; Ungson vd., 1997:48,50). Tarım toplumundan sanayileşmiş bir ekonomiye dönüşen Güney Kore'nin 1970 ve 1980'lerin başlarında devlet öncülügünde uygulamaya koyduğu kalkınma stratejisi ile gösterdiği büyüme dikkat çekicidir. Doğal kaynakları az, ancak beşerî kaynaklar bakımından zengin olan Güney Kore 1960'lı yılların başından itibaren kalkınma stratejisinde köklü bir değişikliğe gitmiştir (Henderson vd., 2002:10). 1960'lı y1lların başlarında Birinci Beş Yıllık Plan Dönemi'nde (1962-1966) başlatılan ve sonraki plan dönemlerinde sürdürülen dışa yönelik kalkınma stratejisine ekonominin dış ticarete aşırı bağımlılığı yönünde eleştiriler olsa bile ihracat, Güney Kore'de ekonomik kalkınmada daima ön planda tutulmuştur.

Söz konusu dönemde ihracata yönelik kalkınma stratejisine geçişte ticaret rejimleri değiştirilerek ithal ikameci kapalı bir rejimden ihracatı destekleyen daha liberal bir rejime geçilmiştir. Güney Kore bu doğrultuda uluslararası ticarette işçilik yönünden mukayeseli 
üstünlüğünü artırmış ve böylece emek-yoğun sanayi ürünleri ihracatı giderek artmıştır (Imaoka, 1990:31). Hükümet bu politikayı uygularken vergi kolaylıkları, selektif kredi dağıtım sistemi ve sübvansiyon gibi araçlardan yararlanmıştır. Ayrıca çok açık seçik olarak anlaşılması kolay, ödüllendirme esasına dayalı yeni ihracatı teşvik sistemleri geliştirilmiş ve bunları kapsamlı bir şekilde uygulamaya koymuştur. Bu uygulamaların esasları kısaca aşağıdaki gibidir (TURKTRADE, 1988:30-32):

- Teşvik edilecek bir şirketin tespiti doğrudan ihracat hacmi miktarının değerlendirilmesi yoluyla yapılır.

- Devlet-özel sektör ilişkileri sıkı disiplin ve denetim altında olup herhangi bir şirket hak etmediği ayrıcalıklı muameleye tabi tutulmaz.

- Herhangi bir nedenle teşvik edilen şirket devlete karşı belirli bazı yükümlülükleri yerine getirmekle sorumludur. Bunlar; üretkenlik, işçi haklarını çiğnememek ve onları eğiterek uzmanlaştırmak, yabancı teknolojiyi ülkeye getirmek, Ar-Ge birimleri kurmak, gümrük duvarlarının altında cazip hale gelen iç piyasaya üretim yapmak ve dış piyasaya yönelmek olarak sıralanabilir.

Özel şirketler sübvansiyonlarla ve ayrıcalıklarla teşvik edilmelerine rağmen sıkı gözetim ve denetin altında tutulduğu aşağıdaki durumlar da bulunmaktadır (Eski, 1989:3132):

- Disiplini ve denetimi sağlayabilmek için teşvik edilecek şirketlerin sayısı sınırlandırılmıştır. Elektronik, gemi ve otomotiv sanayilerinde optimum kapasitesi yüksek olan çok az sayıda şirkete ayrıcalık tanınmış ve böylece ölçek ekonomileri oluşmuştur. İhracatın artmasını sağlayan sayıları onu geçmeyen şirketler zamanla dev kuruluşlar haline gelmiştir.

- İç piyasaya hâkim olan az sayıdaki bu dev işletmelerin tekelci eğilimlerine önlem olarak ithalat ve fiyat denetimleri uygulanmıştır.

- Yatırımcıların ülke dışına sermaye kaçırmasına ve likit sermaye tutmasına engel olmak amacıyla 1960'ların başında bir yasa çıkartılmıştır. Bu yasa, bir milyon dolar ve üzerindeki sermayenin yasal yollar dışında ülke dışına çıkarılması durumunda on yıl hapisten ölüm cezasına kadar ağır cezaları içermiştir.

- 1980'li yılların ortalarına kadar ülkedeki ticari bankaların tamamının sahibi olan devlet, finansman alanını ve bankaları çok sıkı bir şekilde denetlemiş, uygun gördüğü şirketlere kredi vermiştir. Ancak bunun karşıllğında şirketlere hedef göstermiş ve bu hedefe ulaşmayı zorunlu kılmıştır.

İhracatı geliştirerek kalkınmak amacıyla yukarıda sözü edilen Park'ın üzerinde durduğu iki ana konu çerçevesinde hayata geçirilen devlet yapısı kapitalist piyasa ekonomisi olmakla birlikte, bu süreçte devletin gerektiğinde müdahalelerde bulunarak piyasa ekonomisine yön vermesiyle kalkınmada çok önemli bir rol oynadığı açıkça görülmektedir.

\subsubsection{Kalkınmada kamu kuruluşlarının ve bürokratların rolü}

Güney Kore'nin hızlı ekonomik büyümesinin ardında birçok faktör rol almakla birlikte piyasa ekonomisine yön verecek kamu kuruluşlarının oluşturulmasının önemi yadsınamaz. Nitekim o zamanın yöneticileri, ülkelerinde Japonya'ya benzer şekilde doğal kaynaklarının kıt ve sanayileşmelerinin geç kaldığının farkında olarak, sömürge döneminin de etkisiyle Japon kurumlarına benzer kurumlar oluşturmuşlardır (Vogel, 1991). Bunlardan ilki, ihracata yönelik kalkınma stratejisinin hedeflerinin belirlenmesi ve uygulanmasından sorumlu olan Kore Ticaret ve Sanayi Bakanlığı'dır. İkincisi, ekonomiye yön veren en büyük devlet kurumu 
olan Ekonomik Planlama Kurulu (Economic Planning Board-EPB)'dur. Başkanı Devlet Başkan Yardımcısı olan bu kurum devlet bütçesini hazırlamak ve uygulamaktan, kaynak dağılım planlarını yapmaktan, kalkınma planlarını hazırlamaktan sorumludur. Diğer önemli kurumlar arasında; yaptığı araştırma geliştirme faaliyetleriyle EPB'ye destek olmak için kurulan Kore Kalkınma Enstitüsü (Korea Development Institute-KDI) ile sanayileşmeyi teknolojik olarak desteklemek üzere oluşturulan Bilim ve Teknoloji Enstitüsü (Korea Institute of Science and Technology-KIST) bulunmaktadır. Ayrıca ekonomiye yön veren diğer kuruluşlar arasında Güney Kore'nin ihracata yönelik kalkınma stratejisine destek vermek amaciyla kurulan Kore Tüccarlar Birliği (Korea Traders Association-KTA) ve Kore Ticaret Merkezleri aracılığıyla dış pazarlara ihracat olanaklarını araştırarak işadamlarına bilgi ve hizmet sunmak üzere 1962 yılında kurulan ve yurt dışında da teșkilatlanan Kore Ticareti Geliştirme Kurumu (Korea Overseas Trade Association-KOTRA) bulunmaktadır (Eski, 1989:58-60; Hiemenz, 1999:145; Öz, 2008:37-38).

Güney Kore'de bürokratlar işveren ile çalışan kesim arasında bir köprü konumunda olup girişimcileri, üretimi ve ihracatı sürekli desteklemişlerdir. Ayrıca Hong (1987:16) bürokratların çalışma anlayışı ve düzenini şu şekilde ifade etmektedir: "Bugün bile tipik bir beyaz yakalı Kore'li evini sabah saat 7.00 'de terk eder ve işinden akşam saat 8.00 'de ayrılır. Zorunlu gördüğü zaman evinde de işine kapanır. Eğer bitmemiş işler, çözümlenmemiş sorunlar çıkarsa cumartesi ve pazar günleri de çalışmasını sürdürür. Bunu bir zorlama ile değil, toplumsal değer yargısıyla ve kişisel olarak duyacağı haz için yapar." Buradan anlaşılmaktadır ki diğer gelişmekte olan ülkelerde girişimcilerin karşısındaki en büyük engellerden birisi olan bürokratlar Güney Kore'de farklı hareket ederek kalkınmaya önemli katkıda bulunmuşlardır.

\subsubsection{Devletin piyasanın işleyişine müdahalesi}

Güney Kore'de hızlı kalkınma döneminde uygulanan devletin yönlendirdiği ekonomik düzene henüz uygun düşen bir kavram bulmak zordur. Ekonomik yaşamda dinamiklik sağlayan bu düzende "devlet-işletmeler-vatandaşlar" kendi arasında bilinçli, sistematik bir kaynaşma ve uyum sağlama yeteneğine sahiptir. Ne sosyalist ülkelerde ne de serbest piyasa ekonomisi uygulayan ülkelerde böyle bir dinamizme şahit olunmamıştır (Hong, 1987:19). Güney Kore'de hızlı ekonomik kalkınmada devletin uyguladığ 1 politika "merkezi plan ekonomisi" değildir. Burada devletin rolü, yerleşmiş gelenekleri ve adetleri esas alarak, toplumdaki bütün güçleri birleştirerek kalkınmayı kolaylaştırmak olmuştur.

Sanayileşme, Güney Kore'de de diğer gelişmekte olan birçok ülkede olduğu gibi "uyarılmış sanayileşme" olarak başlamıştır. Devlet ekonominin işleyişine doğrudan ve dolaylı müdahalelerde bulunarak sanayi sektörünün gelişmesini sağlamaya çalışmıştır (Eski, 1989:61). Anlaşılacağı üzere piyasa ekonomisinin ülkede uygulanması bazı sınırlamalarla mümkün olmuştur. $\mathrm{Bu}$ durum batıda uygulanan piyasa ekonomilerine göre daha başarılı olmanın anahtarı rolünü üstlenmiştir. Nitekim batıda piyasa sisteminin yapısını ve işleyişini bozabilecek doğrudan müdahalelerde bulunmak uygun kaçmazken Güney Kore'de miktar kısıtlamaları, fiyat kontrolleri, bazı sektörlere özel ayrıcalıklar vb. gibi devlet müdahaleleri uygulanmiştır.

\subsubsection{Yabancı sermaye yatırımlarının teşviki}

İhracata yönelik kalkınma stratejisini başlatan Park yönetimi başlangıçta bunu başarmanın yollarından birisi olarak yabancı sermayenin ülkeye çekilmesinin bu nedenle de özendirici tedbirlerin alınması gerekliliğinin farkındaydılar.

Nitekim hükümet ihracata yönelik kalkınma stratejisini başlattığı ilk yıllarda, öncelikle Güney Kore'nin teknik bilgi kapasitesini geliştirecekler olmak üzere sanayi dallarının 
tümünde yabancı sermaye yatırımlarına çeşitli teşviklerde bulunmuştur (TÜSİAD, 1978:26). Böylece Güney Kore'ye giren yabancı sermayede artış kaydedilmiş, nitekim 1965 yılında bu rakam 49 milyon dolar iken 1975 yılında 1.35 milyar dolara, 1980'de ise 3.01 milyar dolara yükselmiştir (Imaoka, 1990:36). 1983 y1lı itibariyle bu yatırımların yüzde 49'u Japonya, yüzde 28'i ABD ve yüzde 12'si Batı Avrupalı yatırımcılar tarafından yapılmıştır (Çakıroğlu, 1987:12).

Yabancı sermayenin ülkeye girişinin önünü daha da açmak ve o zamana kadar uygulanan bazı engellemeleri de kaldırmak amaciyla 1 Temmuz 1984 yılında Yabancı Sermayeyi Teşvik Kanunu yürürlüğe konmuştur. $\mathrm{Bu}$ kanunla yabancı yatırımcıların başlangıçta taahhüt ettikleri ihracatı gerçekleştirememeleri halinde uygulanan cezalar hafifletilmiş, ayrıca yabancı sermaye ile ortak yatırımlarını tercihli sahalara yapan şirketlere, ortaklıkları oranında kurumlar, kazanç ve emlak vergilerinden beş yıl süreyle muafiyet imkânı tanınmıştır. Tercihli alanlar; Güney Kore'nin ödemeler bilançosunun düzelmesine büyük oranda yardımcı olacak projeler, ülke dışında daimî ikamet edenlerin Güney Kore'de geliştirdikleri projeler, ileri teknoloji ve büyük sermaye yatırımlarına ilişkin projeler ve serbest ticaret bölgelerindeki projeler olarak siralanabilir (TÜSİAD, 1985:14-17). Ancak kanunla su işleri, drenaj, posta hizmetleri, sağlık hizmetleri, telgraf, telefon, demiryolu taşımacılığı sigara ve ginseng ${ }^{5}$ üretimi gibi devlet tarafından yapılan işlerde yabancı yatırıma izin verilmemiştir (Çakıroğlu, 1987:12-13).

Kanunla Serbest Ticaret Bölgeleri'ne yabancı yatırımcıların gelmesinin teşvik edilmesiyle, öncelikle yabancı sermaye yatırımlarını uyararak ihracatı geliştirmek, istihdam olanaklarını artırmak ve ayrıca ülkeye modern teknoloji transferini sağlayarak Güney Kore'nin ekonomik gelişmesinin desteklenmesi amaçlanmıştır (Berberoğlu, 1986:120-121). Bu bölgelerin kurulması ve geliştirilmesi için yatırım için yatırılan meblağın yüzde 6'sı (yerli imalatta yüzde $10^{\prime} u$ ) oranında gelir ve kurumlar vergisinden indirim yapılmış ya da yüzde 50 oranında özel amortisman teşvikleri uygulanmıştır (TÜSİAD, 1985:19). Güney Kore'nin ekonomik ve siyasal olarak gösterdiği istikrara ilave olarak yabancı sermayeye yönelik sergilenen güven verici davranışlar ile ülkeye yapılan yabancı sermaye yatırımları artmıştır.

Güney Kore’nin hızlı ekonomik büyümesiyle birlikte iç pazarının genişlemesi, yabancı sermayenin Uzakdoğu'nun diğer ülkelerin pazarlarına Güney Kore üzerinden girme düşüncesi ülkeye yabancı ülkeler tarafından yatırım yapılmasının diğer sebepleri olarak ifade edilebilir (Kihwan, 1987:35-36).

\subsubsection{Planlamacılığın rolü}

Kaynak yetersizliğinin ve yurtiçi piyasasının sınırlı olmasının neden olduğu ekonomik zayıflığın giderilmesi amacıyla 1960'lı yılların başlarında Park yönetimi tarafından başlatılan ihracata yönelik kalkınma stratejisinin başarıya ulaşması amacıyla planlamacılığa önem verilmiş ve ekonomik kalkınma planlarının hazırlanarak uygulanmasına ihtiyaç duyulmuştur.

Bir plana bağlı olarak ülkenin kalkınması amacıyla Güney Kore'de çok güçlü bir planlama teşkilatı kurulmuştur. Planlama teşkilatı planlamayı yaparken üretim alanlarından hangisine öncelik verileceğini, işgücü kullanımını ve ihracat potansiyelini göz önüne almıştır (Berberoğlu, 1986:118). Nitekim planlar incelendiğinde yurtiçi tasarrufların yükseltilmesi, ihracatın teşvik edilmesi, altyapının güçlendirilmesi, seçili ürünlerde ithal ikamesi sanayilerin geliştirilmesi ve tarımsal gıda maddelerinde ülkenin kendi kendine yeterliğinin sağlanmasının temel hedefler olduğu görülmektedir.

\footnotetext{
${ }^{5}$ Ginseng: Güney Kore’de ilaç yapımında kullanılan bir çeşit köktür.
} 
Çalışmamızın kapsamında olan ilk yedi plan döneminin genel özelliklerinin neler olduğu, hangi plan döneminde hangi sektörlere ağırlık verildiği ve hangi ürünlerin üretimlerinin tercih edildiği aşağıda kısaca özetlenmiştir (Berberoğlu, 1986:118; Kore Gerçeği, 1991:59; Sadıklar, 1989:35; Eski, 1989:68-69; (Savada \& Shaw, 1990):

- Birinci ve İkinci Kalkınma Plan Dönemlerinde (1962-1971) sanayileşmenin temellerini hazırlayabilmek için çaba gösterilmiş ve ancak geçimini sağlayabilen tarım sektöründen sanayileşme yönünde modern imalata ve ihracata dayalı yeni yapısal düzenlemelere gidilmiştir. Bu kapsamda Birinci Beş Yıllık Kalkınma Plan Döneminde elektrik, gübre, petrol rafinerisi, sentetik iplikler, çimento gibi üretimlere ağırlık verilmiştir. İkinci Beş Yıllık Kalkınma Döneminde de sentetik iplikler, petrokimya ürünleri, elektrik aksamları, televizyon ve buzdolabı gibi ürünlerin üretimlerine ağırlık verilmiştir.

- Üçüncü Beş Yıllık Kalkınma Plan Döneminde (1972-1976) genellikle ağır sanayi ve kimya sanayi dallarının teşviki önem kazanmıştır. Ağır sanayi dallarından demir-çelik üretimi, ulaşım makinaları ve gemi yapımına özel önem verilmiş ve teşvik edilmiştir.

- Dördüncü Beş Yıllık Kalkınma Plan Döneminde (1977-1981) yurtiçi tasarrufların teşviki ve cari işlemlerde fazlalık sağlanmaya çalışılmış, ağır sanayi ürünleri, yüksek teknolojiyi gerektiren makine ve elektrik üretimine geçilmesi hedeflenmiştir. Ancak yurtiçi tasarrufların teşviki ve cari işlemlerde fazlalık sağlanmasında iç ve dış sorunların meydana gelmesi nedeniyle hedefe ulaşmada başarılı olunamamıştır.

- Beşinci Beş Yıllık Kalkınma Plan Döneminde (1982-1986) ise sektörler arasında meydana gelen dengesizlikler giderilmeye çalışılmıştır. Ayrıca daha önceki dönemlerden süregelen enflasyonla sıkı para politikası uygulanarak mücadele edilmiş ve başarılı olunmuştur. $\mathrm{Bu}$ dönemde imalat sanayinde verimliliğin artırılması ve sosyal adaletin güçlendirilmesi için çeşitli adımlar atılmıştır. Bu plan dönemindeki başarı Güney Kore ekonomisinin büyüme sürecini yeniden istikrara kavuşturmuştur.

- Altıncı Beş Yıllık Kalkınma Plan Döneminde (1987-1991) de uzun vadeli hedeflerin gerçekleştirilmesi yolunda ilk adım atılmıştır. Bu amaçla Güney Kore sanayisinin teknolojik standartlarının yükseltilerek iç büyüme ve dış ticarette büyümenin sağlanması hedeflenmiştir. $\mathrm{Bu}$ dönem uzun vadeli hedeflerin ön plana çıktığg dönemdir.

Yedinci Beş Yıllık Kalkınma Plan Döneminde (1992-1996) olgunlaşma dönemine giren Güney Kore ekonomisinin büyümesinin sağlanması için yükssek teknolojili üretim alanlarının geliştirilmesine yönelik çabalar başlatılmıştır. Ayrıca bu plan döneminde sanayi üretim tesislerinin ülke çapında dengeli dağılımı, sosyal ve ekonomik eşitliğin sağlanması ile eğitim ve öğretim sistemi reformunun gerçekleştirilmesi hedeflenmiştir.

Güney Kore'de planlamacılık, ihracata yönelik kalkınma stratejisinin başlamasından itibaren kalkınmanın temel taşlarından biri olarak kabul edilmiş ve sürekli geliştirilmiştir. Buradan hareketle planlamanın hızlı kalkınmada bir anahtar olarak büyük rol oynadığı karşımıza çıkmaktadır.

\subsubsection{Ar-Ge ve İnovasyonun Rolü}

Dünyanın içinde olduğu sürekli değişim ve gelişimin bir sonucu olarak ortaya çıkan teknolojik gelişim aynı zamanda diğer ülkelerle olan rekabette bir güç unsuru ve varoluş mücadelesi haline gelmiştir. Bu kapsamda inovasyon ve yeni teknolojilerin kullanılarak yüksek katma değerli ürünlerin üretilmesi ve bunların ihraç edilerek ekonomiyi canlandırması için Ar-Ge faaliyetleri ön plana çıkmıştır (Canbay, 2020:866). Bu durumun farkına varan Güney Kore 1980'lerden itibaren Ar-Ge sisteminin geliştirilmesi için harcamalarını artırma ve 
yüksek katma değerli ileri teknoloji içeren ürünlerin üretilerek ihraç edilmesine yönelik adımlar atmaya başlamıştır.

Güney Kore'yi kendi teknolojisini geliştirmeye zorlayan nedenlerin başında Güney Kore'nin 1980'lere kadar gösterdiği gelişim süreci sonucunda Japonya gibi gelişmiş ülkelerin hâkim sektörlerinin pazarlarına girmeye çalışmasından dolayı bu ülkelerin teknoloji transferi konusunda isteksiz davranmaya başlaması olmuştur. Bu ülkeler tersine mühendislik yaparak taklit ürün üretimini engellemek için telif hakları ve patent yasalarını da değiştirmiştir (Kim ve Dahlman, 1992:441). Tüm bu etkenler Güney Kore'nin bilgiye dayanan ekonomisini oluşturması ve geliştirmesi için başlangıç oldu. Böylece ihtiyaç duyulan sektörlere ekonomik teşvik verilmesi, kurumsal rejimin yeniden düzenlenmesi, eğitimli ve donanımlı işgücünün yaratılması, etkili bir inovasyon sisteminin oluşturulması, bilgi teknolojilerinin modernleştirilerek yeterli hale getirilmesi için gerekli adımlar atılmaya başlandı (World Bank, 2006:22). Bu kapsamda atılan adımlar genel olarak şu şekilde özetlenebilir: 1) Belirlenen kalkınma hedeflerine ulaşabilmek için stratejik kaynakların devlet liderliğinde seferber edilmesi; 2) İhracatın teşvik edilerek hızla pazarın genişletilmesi; 3) Özellikle ağır kimyasallar olmak üzere seçili endüstriyel ürünlerin teşvik edilmesi; 4) Devletin büyük şirketleri geliştirmek için desteklemesi; 5) Yabancı teknolojilerin kullanılması; 6) Endüstriyel talepler için bilim ve teknoloji altyapısını kurmak ve Ar-Ge programları yapmak (Suh, 2000:23). Bunların her biri birbirlerini tamamlayan girişimler olsa da Ar-Ge programlarının hayata geçirilerek yeni teknolojiler geliştirilmesiyle ihracatı artırmak adına inovasyonun önemi diğerlerine göre daha fazladır.

Güney Kore'de Ar-Ge ve İnovasyon sürecini üç döneme ayırmak mümkündür. 1960’l1-1970'li yılları kapsayan, emek-yoğun düşük teknolojili sektörlerin öne çıktığı, az da olsa yabancı yatırımcıların yatırım yaptığı, endüstrileşmede teknoloji transferinin başladığı 'İmitasyon Dönemi' birinci dönemdir. 'Transformasyon Dönemi' olarak adlandırılan ikinci dönem 1980'li yılları kapsamaktadır. Bu dönemde ithal ikameci ve korumacı politikaların uygulamaları azalmaya başlamıştır. Ayrıca hükümet tarafından imitasyon döneminde uygulanan teknoloji transferinin ve üniversiteler ile kamu sektörünün gerçekleştirdiği araştırmaların yetersiz olduğu düşünülmüş, bu nedenle özel sektörün kendi Ar-Ge yapılarını kurmaları ve geliştirmeleri teşvik edilmiştir. 1990'l yılları ve sonrasını kapsayan son dönem olan ‘İnovasyon Dönemi'nde Asya Krizi’nin de etkisiyle teknoloji politikaları yeniden gözden geçirilmiş, bu çerçevede büyük sanayi şirketlerine göre inovatif, dinamik ve daha esnek yapıya sahip olan KOBI'lere yönelinmiş ve bunların Ar-Ge harcamalarında artış gözlenmiştir. Stratejik kararlarla Ar-Ge politikaları belirlenen odak sektörlere yönelik olarak hazırlanarak uygulanmıştır. Bu kapsamda özellikle nano-teknoloji ve biyo-teknoloji alanlarına yapılan yatırımlar artmıştır. Böylece arzu edilen getiri seviyelerine daha hızlı ulaşılabilmiştir (Arslanhan ve Kurtsal, 2010:1-2, 12). Güney Kore 21. yüzyıla gelindiğinde G-7 ülkelerinin gelişmişlik düzeyine ulaşmak amacıyla 1990'lı yıllarda sanayisini yeniden yapılandırmaya ve inovasyonu desteklemeye odaklanmıştır. Bu kapsamda 1992 yılında 'Son Derece Gelişmiş Ulusal (Highly Advanced National) Projeler'i uygulamaya koymuştur. Bu projelerle sanayinin gelişiminde büyük rol sahibi olan Chaebol'lerin yatırımlarıyla hükümet yatırımları birleştirilmiştir (Rhee, 2003:58). 
Tablo 3. Güney Kore'nin Ar-Ge Harcamaları ve Patent Sayıları

\begin{tabular}{|c|c|c|c|c|c|c|c|c|}
\hline Yıllar & $\mathbf{1 9 6 0}$ & $\mathbf{1 9 6 3}$ & $\mathbf{1 9 7 0}$ & $\mathbf{1 9 8 0}$ & $\mathbf{1 9 9 0}$ & $\mathbf{2 0 0 0}$ & $\mathbf{2 0 1 0}$ & $\mathbf{2 0 1 9}$ \\
\hline GSYİH \% & - & 0,25 & 0,39 & 0,56 & 1,71 & 2,1 & 3,3 & 4,6 \\
\hline Patent SayıSı & 611 & 771 & 1,846 & 5,070 & 25,820 & 102,010 & 170,101 & 218,975 \\
\hline
\end{tabular}

Kaynak: OECD; Yim, (2004:5); World Bank, (2006:37); Korean Intellectual Property OfficeKIPO.

Tablo 3 incelendiğinde, Güney Kore'nin GSYİH içindeki Ar-Ge harcamaları paylarının 1963 yılında \%0,25, 1980 yılında ise \%0,56 seviyelerinde olduğu görülmektedir. 1990'lı yıllardan itibaren başlayan inovasyon döneminde Ar-Ge çalışmalarına verilen önem ve politika değişiklileriyle bu pay giderek artış göstermiştir. Nitekim 1990 yılındaki oran 1,71 iken, 2010 yılında 3,3'e 2019 yılında ise \%4,6'ya yükselmiştir. Ar-Ge harcamalarına ayrılan payın artışı, teknolojik gelişmenin de bir göstergesi olarak kabul edilebilecek patent sayılarına da yansımıştır. Yine Tablo 3'te görüleceği üzere 1960 yılında sadece 611 olan patent sayıs1 1990 yılında 25,820'ye 2019 yılında ise 218,975'e ulaşmıştır.

Tablo 4. Güney Kore İhracatının Ürün Bileşimindeki Eğilimi (\%)

\begin{tabular}{|c|c|c|c|c|c|c|}
\hline Yıllar & $\mathbf{1 9 6 2}$ & $\mathbf{1 9 7 2}$ & $\mathbf{1 9 8 0}$ & $\mathbf{1 9 9 5}$ & $\mathbf{2 0 0 0}$ & $\mathbf{2 0 1 1}$ \\
\hline Temel Sanayi Ürünleri & 72,3 & 11,1 & 7,7 & 4,9 & 2,8 & 2,8 \\
\hline Endüstriyel Ürünler & 27,7 & 88,9 & 92,3 & 95,1 & 97,2 & 97,2 \\
\hline Hafif Sanayi & - & 67,4 & 48,4 & 19,9 & 16,2 & 6,2 \\
\hline Ăğır Sanayi & - & 21,5 & 43,9 & 75,2 & 81 & 91 \\
\hline
\end{tabular}

Kaynak: Korea Economic Institute, (2012:23).

Transformasyon döneminde başlayan ve inovasyon döneminde de devam eden Ar-Ge harcamaları ve patent sayılarındaki artış ihracat ürün bileşiminde de ters yönde dönüşüm içine girmiştir. Kalkınma hamlesinin başladığ 1 yıllarda temel sanayi ürünlerinin ihracat içindeki payı endüstriyel ürünlerin payına göre oldukça yüksek iken kalkınmanın sağlandığı inovasyon dönemini kapsayan yıllarda durum tam tersine dönmüştür. Durum Tablo 4'te açıkça görülmekte olup, ihracat ürün bileşiminde temel sanayi ürünlerinin payı 1962 yılında \%72,3 iken bu pay 2011 yılında \%2,8'e kadar gerilemiştir. Aynı yıllar için endüstriyel ürünlerin payı sırasıyla \%27,7’den \%97,2 gibi çok yüksek bir orana ulaşmıştır.

İnovasyon döneminde teknolojik gelişmeye önem verilmesiyle birlikte Ar-Ge harcamalarının da arttığı görülmektedir. Böylece Güney Kore'nin ekonomik kalkınmasındaki başarısında etkin rol oynayan geliştirilen Ar-Ge ve İnovasyon sistemi yeni teknolojilerin geliştirilmesini ve ekonomik büyümenin sürdürülebilir hale gelmesini sağlamıştır. 


\subsection{Güney Kore Ekonomisinin Gelişmesinde Karşılaşılan Başlıca Sorunlar}

Finansal sorunlar: Güney Kore'de yönetim 1960’lı yılların başından itibaren reel faiz politikası uygulamalarıyla tasarrufların artırılmasını teşvik etmiştir. Ancak biriken tasarruflardan sanayi sektörünün geliştirilmesi amacıyla bankalardan yüksek miktarda kredi alan firmalar devlet bankalarına baskı uygulayarak aldıkları kredilerin negatif reel kredi faizi olarak uygulanmasını kabul ettirmiştir. 1972 yılında başlayan bu uygulamayla hükümet, bankalarda sınırlı bulunan ödünç verilebilir fonları seçtiği büyük firmalara dağıtmaya başlamıştır (Eski, 1989:71). Bunun sonucu olarak tasarruf sahipleri hükümete olan güvenini yitirmiş ve Tablo 2'de de görüleceği üzere tasarruflarda azalma meydana gelmiştir.

Hükümet tasarruf potansiyelinden yeterince yararlanamayınca yine Tablo 2'de görüldüğü gibi enflasyonist finansman yöntemlerine başvurmuş ve diş borçlarda hızlı bir artış görülmüştür. Böylece kredi alan firmaların finansman yapısı giderek bozulmuş ve uzun dönemde uygulanan kredi dağıtım politikasına bağımlılıkları artmıştır (Hong, 1987:33-34). Anlaşılacağı üzere Güney Kore'de devlet eliyle yönlendirilen kredi dağıtım politikası piyasa mekanizmasını ve kaynak dağılımını önemli oranda bozmuştur.

Dev şirketlerin meydana gelmesi ve devlete baskıları: Daha önceden ifade edildiği gibi Güney Kore'de ailelerin egemen olduğu şirket gruplarına "chaebol” adı verilmektedir. Büyük ölçekli bu dev şirketler Güney Kore ekonomisinin hem temelini oluşturmakta hem de etkisi altına almaktadır.

Chaebol'ler Japonya'daki Sogo Shosha'lara benzer yapıdadırlar. Chaebol'lerin en büyükleri arasında Daewoo, Samsung, Hyundai ve Lucky-Goldstar yer almaktadır. Bu gruplar ihracata yönelik kalkınma stratejisinin başlatılmasından önce kurulmuşlar ve hızla büyümüşlerdir. Chaebol'ler çelik ürünleri, kimyasal ürünler, gemi yapımı, televizyon, elektronik ev aletleri, yarı iletkenler ve lazer gibi üretim dallarında faaliyet göstererek oldukça geniş bir sahayı işgal etmektedir (TÜSİAD, 1986:20-21). Görülüyor ki chaebol'ler istihdam, üretim, ihracat, yatırım ve prodüktivite yönüyle ülkenin ekonomik gidişatını belirleyecek güce sahiptir. Ancak bunlar birbirleriyle amansız bir rekabet içinde olmuştur. Bu nedenle her biri devleti etkileyerek sübvansiyon ve vergi avantajını ele geçirerek bu rekabetten üstün çıkmaya çalışmıştır.

Güney Kore ekonomik yapısı içinde chaebol'lardan başka dağınık küçük işletmeler bulunmakla birlikte bunlar sağlıklı, güç dengesizliğini giderici ve bağımsız orta sınıf girişimci firmalardan meydana gelmemiştir.

Siyasal yapıdaki dengesizlikler: Güney Kore'de güç ve çıkar çatışmasında olan önemli gurupları askerler, seçkinler ve büyük sanayiciler olarak üçe ayırabiliriz. Bunlar ekonomik ve siyasal olarak güçlerini birbirleriyle sürekli sınamıştır. Başkanlar otoritelerini bu gruplarla anlaşabildiği ölçüde sürdürebilmiş, biriyle veya birkaçıyla uzlaşamadıklarında kendi sonlarını hazırlamışlardır (Eski, 1989:76).

Güney Kore Mayıs 1961 darbesiyle birlikte asker kökenli rejimler tarafından yönetilmeye başlanmış ve başkan olan askerler sırtını eski silah arkadaşlarına dayayarak otoriter rejim uygulayan birer politikacı olmuşlardır. Ancak otoriter politikaları gereği ülkenin ekonomik ve siyasal politikası hakkında muhalefete hiçbir bilgi verme gereği duymamışlardır. Siyasal yapıdaki dengeyi sağlamak amacıyla 1987 yılında kabul edilen anayasayla demokrasi yönünde adımlar atılmış ve uzun bir aradan sonra Roh Tae Woo seçimle devlet başkanı olmuştur.

Küçük sanayici, esnaf, tüketici, işçi, köylü, emekli vb. gibi çoğunluğu oluşturan halkın istek ve düşünceleri ekonomik ve siyasi kararlarda belirleyici olmamıştır. Ancak buna karş1lık 
büyük sanayi grupları ekonomik ve siyasi kararların alınmasında oldukça etkili olmuş ve isteklerini yaptırmıştır.

Sosyal göstergelerdeki dengesizlikler: Ekonomideki refah göstergelerinden birisi olan kişi başına düşen milli gelir 1960 yılında sadece 158 dolar iken, 1990 yılına kadar hızla artarak 6.610 dolara yükselmiş, 2020 yılına gelindiğinde ise 31 bin doları aşmıştır. Ancak sosyo-ekonomik yaşam standardını gösteren bu istatistikler ortalama değerleri gösterdiğinden kişilerin refah seviyelerini göstermekten uzaktır. Bu nedenle toprak mülkiyetinin dağılımı, barınma olanakları ve konut sahipliği, sosyal güvenlik ve çalışma koşulları sosyal refahın dağılımı konusunda bilgi verebilecektir.

Ülkede bağımsızlığın kazanılmasından sonra çeşitli tarım reformlarıyla topraklar köylülere yeniden dağıtılmıştır. Ancak Güney Kore'nin hızla sanayileşmesi ile birlikte köylerden şehirlere göç başlamış ve tarım sektörü önemini yitirmiştir. Şehirlerdeki aşırı nüfus artışı konut talebini ve arsa fiyatlarını artırmıştır. Bu durum şehir ve kırsal kesim arasında dengesiz konut dağılımına neden olmuştur.

Hızlı bir şekilde kalkınan Güney Kore halkı, diğer gelişmiş ülkelerde birkaç yüzyılda yaşanan değişimleri çok kısa bir süre içinde yaşamak zorunda kalmıştır. Bu durum birçok alanda olduğu gibi sosyal güvenlik alanında da bazı sıkıntılar yaşanmasına neden olmuştur. Nitekim ülkede Sosyal Güvenlik Kanunu 1963 yılında çıkarıldığından sosyal güvenliğin tarihinin çok gerilere gitmediği söylenebilir. Bu nedenle sosyal güvenlik sistemi yeterince gelişme sağlayamamıştır.

Ülkede uygulanan sosyal güvenlik sistemi yalnızca hastalık ve kazaya karşı sigorta ile emekliliği düzenlemektedir. Hastalık sigortası için işletme ve işçilere zorunluluk getirilmiştir. Bu kapsamda sigorta priminin yarısı işçi diğer yarısı da işveren tarafından ödenmiştir. Ayrıca sigorta kurumları ayakta tedavinin yüzde 30'unu yatarak tedavinin yüzde 80'ini üstlenmiştir (Eski, 1989:82-83).

Güney Kore'deki mevcut çalışma hayatına ilişkin yasa ve yönetmelikler beş ve beșten fazla işçi çalıştıran işletmelerde geçerlidir. İşçi sendikaları faaliyetlerinin yasal hükümlerle sınırlandırılması nedeniyle çok zayıf olduklarından işçi haklarını korumakta yetersiz kalmıştır. Ayrıca sendikaların siyasal sorunlara karşı tavır almaları kesinlikle yasaklanmış, ancak şekil olarak greve gidebilmeleri mümkün olmuştur. Ücret artışları genellikle işverenler tarafından tek taraflı olarak belirlendiğinden, haftalık çalışma saatleri memurlara göre daha yüksek olmasına rağmen aldıkları maaş yarısından daha az olmuştur (Eski, 1989:80-81). İşçiişveren uyuşmazlıkları ihracatı ve ekonomik büyümeyi engellememesi düşüncesinden hareketle hükümet tarafından işveren lehine baskı yoluyla kararlar alınarak çözümlenmiştir (Kore Gerçeği, 1991:79-80). Bunlar gerek hükümetin gerekse işverenin aldığı kararların işçinin refahını gözetmeye yönelik olmadığının açık bir göstergesidir. Bu nedenle işçilerin hakları sendikalar tarafından tam olarak sağlanamadığından işçiler haklarını arzu edilen düzeyde elde edememişlerdir.

\section{SONUÇ VE DEĞERLENDİRME}

Yapılan literatür incelemesinde ihracata yönelik kalkınmaya ilişkin gerek Asya ülkeleri gerekse diğer gelişmekte olan ülkeler için birçok çalışmanın yapıldığ1 gözlemlenmiştir. Bu çalışmalardan çıkarılan sonuçlar şu şekildedir. Yapılan ampirik araştırmaların bir kısmı Granger'in ihracat ile ekonomik kalkınma arasındaki ilişkiyi ölçen iki değişkenli nedensellik testleri ile yapılmıştır. Bir kısmı ise tematik yaklaşımla yapılmıştır. Çalışmaların çoğunda başta Güney Kore olmak üzere Asya ülkelerinde ihracat ile ekonomik kalkınma arasında sıkı bir ilişki olduğu sonucuna ulaşılmıştır. Bununla beraber yapılan bazı çalışmalarda da bu ilişkinin varlığı tespit edilememiştir. Bu çerçevede, eğer gelişmekte olan 
ülkelerde ihracat ve kalkınma arasında bir nedensellik söz konusu ise bir ülkenin gelişmişlik düzeyine ulaşması için ihracatın artırılması bir ön koşul olabilecektir. Bu durumda ihracat ve kalkınma arasında çift yönlü bir nedensellik gerçekleşerek biri diğerini güçlendirebilecektir.

İhracata yönelik kalkınma stratejisine yönelik Güney Kore özelinde yapılan çalışmada ulaşılan sonuçlar şu şekilde özetlenebilecektir: Doğal kaynaklar bakımından sınırlı, Kore Savaşı nedeniyle harap olmuş bir ekonomiye sahip tarım toplumu olan Güney Kore'nin özellikle 1960'lı yıllardan sonra hızla gelişerek kalkınması dikkat çeken bir başarı öyküsü olarak karşımıza çıkmaktadır. Kuruluş yıllarında ve savaştan sonra (1945-1961) ABD’nin yardımlarıyla ekonomisini toparlamaya çalışan Güney Kore, bu yıllarda ithal ikameci sanayi stratejisini uygulamıştır. 1961 Mayıs'ında gerçekleşen askeri darbeyle birlikte bu yıllardan itibaren kalkınma stratejisi tamamen değiştirilerek, piyasa ekonomisi benimsemiş ve ihracata yönelik sanayileşme stratejisi hamlesi başlatılmıştır. Ancak bu süreçte devletin uyguladığı iktisat politikalarıyla gerekli gördüğü durumlarda piyasaya müdahale ve yönlendirmelerde bulunmuştur. Park yönetiminin başlattığı bu kalkınma hamlesinde ekonomik gelişme ve planlamanın gerçekleştirilmesine yönelik birçok reform hayata geçirilmiştir. Bunların içinde önem taşıyanların başında yabancı sermayenin ülkeye çekilmesi için yapılan gerekli düzenlemelerdir. Diğeri ise o yıllarda tek ve en önemli kaynak olan bol ve ucuz işgücü aracılığıyla emek-yoğun sanayi mamullerinin üretilmesi ve bunların ihraç edilerek sanayileşmenin sağlanması olmuştur. Tüm bu çabaların bir plan dahilinde yürütülebilmesi amacıyla "Ekonomik Planlama Kurulu" tarafından kalkınma planları hazırlanmıştır. Bu planlar devletin müdahaleci rolü, ekonomiye yön veren karar alıcı diğer kurumların planların hazırlanmasında rol oynaması ve devletin uygulamadaki sıkı denetimleri sonucunda başarıya ulaşmiştır.

Bunun yanı sıra Güney Kore ekonomisinin gelişmesinde; halkın mevcut geleneksel yapıs1, ahlak ve değer sisteminden oluşan sosyo-kültürel yap1 ve 45 y1l süren Japon sömürgeciliğinin de ülkede bıraktı̆̆ 1 etki ve kurumlar önemli role sahiptir. Bu bağlamda Japonya'yla aynı coğrafyada bulunması nedeniyle benzer özelliklere sahip olması, Japon kültürünün izleri ve Japonya'nın önceden sanayileşmeye başlayarak örnek olması önem taşımıştır. Ayrıca öğrenmeye büyük önem verilmiş, beşerî sermayenin eğitilmesi için çaba sarf edilmiştir. Halkın "ben” yerine "biz" düşüncesine sahip olması da hızlı kalkınmaya neden olan faktörlerdendir.

İhracata yönelik sanayileşmeyi ağır sanayi ve kimya sanayinin kuruluşu ve geliştirilmesi çabaları takip etmiştir. Bu amaçla başlangıçta söz konusu endüstrilere yatırım yapacak olan chaeboller, devlet tarafindan vergi indirimleri sağlanarak ve yurtdışından gelen yardımların Güney Kore Kalkınma Bankası tarafından düşük faizli ve uzun vadeli olarak verilmesiyle desteklenmiştir. Böylece chaeboller hızlı kalkınmada önemli rol oynamışlardır.

Ağır sanayi ve kimya sanayisinin kuruluşu ve geliştirilmesi için uygulanan politikalar 1970'li yılların ortalarından itibaren ekonomide bozulmalara da neden olmuştur. Ülkenin 1960'lı yılların başından beri yakalamış olduğu hızlı ekonomik gelişme aksamış ve gerilemiştir. Ancak bu durumun giderilmesi için 17 Nisan 1979'da yürürlüğe giren geniş kapsamlı istikrar programı uygulamaya konmuş, ancak Park'ın bir suikasta uğrayıp öldürülmesi ve diğer dişsal nedenlerle arzu edildiği gibi yürütülememiştir. İstikrar programı tam anlamıyla Chon Du Hwan'ın göreve gelmesiyle hayata geçirilebilmiştir. 1990'lı yıllardan itibaren Ar-Ge faaliyetleri ve teknolojik projeler sanayinin geliştirilmesi çabalarına kalıcı destek sağlamak amacıyla çeşitli düzenlemeler yapılarak teşvik edilmiştir. Böylece inovasyon dönemine girilerek yüksek teknolojili ürünlerin üretilmeye başlanmasıyla Güney Kore ekonomisi hızlı gelişme trendini yakalamıştır. 
Güney Kore hızlı kalkınmasındaki yolculuğunda finansal, dev şirketlerin meydana gelmesiyle birlikte bunların devlete baskıları, siyasal istikrarsızlıklar ve sosyal göstergelerde meydana gelen dengesizlikler gibi birçok sorunlarla da baş etmek zorunda kalmıştır.

Gelişmekte olan ülkelerin ekonomik kalkınmalarını nasıl ve hızla gerçekleştirebilecekleri kolayca çözülebilecek bir sorun değildir. Dolayısıyla bu ülkelerin söz konusu sorunsalı çözebilmeleri için mevcut başarılı örnek uygulamalardan faydalanmaları yararlı olacaktır. Bu kapsamda sömürge devlet olmaktan ve savaştan çıkmış ve ithal ikameci stratejiden ihracata yönelik sanayileşme stratejisine geçerek Ar-Ge ve inovasyon sistemini geliştiren, bunun paralelinde ekonomik yapısını tamamen değiştirerek emek-yoğun üretimden teknoloji-yoğun üretime geçerek yüksek teknolojili ürünlere yönelen Güney Kore'nin başarı öyküsü gelişmekte olan ülkelere örnek olması bakımından oldukça önemlidir. Elbette ki bu ülkeler benzer stratejiyi uygulamak isteseler de sosyo-kültürel yapı, kamu kuruluşları, bürokratlar, chaeboller gibi dev aile şirketlerinden oluşan girişimciler, vb. gibi faktörler Güney Kore ile aynı olmayacağından sonucun da aynı olmamasına neden olabilir. Bu nedenle Güney Kore'nin yaptığı gibi her ülkenin kendisine özgü bir modeli günün koşullarına göre belirlemesi gerekir. Bundan başka, her ülke kalkınma süreçlerinde içinde bulundukları dönemden etkilenseler bile, Güney Kore örneğinde olduğu gibi kalkınma sürecinin başlangıcında devletin ekonomiyi yönlendirmesi ve müdahalesi kalkınma açısından önem taşımaktadır.

\section{Kaynakça}

Ağayev, S. (2011). Relationship between Export and Economic Growth: Panel Cointegration and Panel Causality Analysis in 12 Transition Economies Case . Ege Academic Review, 11(2), 241-254. https://dergipark.org.tr/en/pub/eab/issue/39889/473482 (Erişim Tarihi: 02.08.2021).

ANA BRITANNICA. (1989). Kore Cumhuriyeti. C. 13.

Arıkan, A. (1986). Güney Kore Ekonomisinde Son Gelişmeler. İGEME Dış Ticaret Bülteni (20 Haziran 1986), 24(24).

Arslanhan, S. ve Kurtsal, Y. (2010). Güney Kore İnovasyondaki Başarısını Nelere Borçlu? Türkiye İçin Çıkarımlar. TEPAV Politika Notu, 1-15. https://www.tepav.org.tr/upload/files/1285828695-

5.Guney_Kore_Inovasyondaki_Basarisini_Nelere_Borclu_Turkiye_icin_Cikarimlar.p df (Erişim Tarihi: 26.07.2021).

Aslan, C. ve Taner, A. (2016). Kalkınma Hamlelerinin Batı Dışı Örnekleri: Türkiye ve Güney Kore'nin Karşılaştırılması. Adam Akdemi Sosyal Bilimler Dergisi, 6(1): 27-58, Ankara.

Balassa, B. (1978). Exports and Economic Growth: Further Evidence. Journal of $\begin{array}{lll}\text { Development } \quad \text { Economics, } & \text { 181-89. }\end{array}$ https://www.sciencedirect.com/science/article/abs/pii/0304387878900068 (Erişim Tarihi: 06.07.2021). https://doi.org/10.1016/0304-3878(78)90006-8

Bank of Korea. Korea System of National Accounts. https://www.bok.or.kr/eng/bbs/E0000746/list.do?menuNo=400228\&searchWrd=GRO

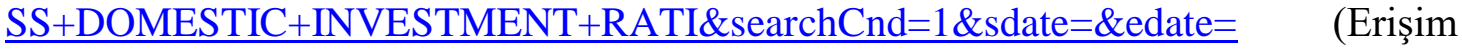
Tarihi: 09.08.2021).

Berberoğlu, C. N. (1986). Güney Kore Masan Serbest Bölgesi. Anadolu Üniversitesi, İdari Bilimler Fakültesi Dergisi (Haziran), 4(1), Eskişehir. 
Canbay, Ş. (2020). Investigation of the Effect of Turkey's High-Tech Exports on the Economic Growth Using the Structural Break ARDL Bounds Testing. Elektronik Sosyal Bilimler Dergisi, 865-878. https://dergipark.org.tr/tr/pub/esosder/issue/53245/657480 (Erişim Tarihi: 10.06.2021). https://doi.org/10.17755/esosder.657480

Chung, K. H., Lee, H. C. ve Jung, K. H. (1997). Korean Management: Global Strategy and Cultural Transformation. New York: Walter de Gruyter, Berlin, New York.

Çakıroğlu, D. G. (1987). Güney Kore. İGEME Dergisi Dış Ticaret Bülteni Eki (9 Ocak), 25(2).

Çakmak, N. S. (2015). Güney Kore Toprak Reformunun Ekonomi Politiği. Marmara Üniversitesi, $\quad$ İ.̇̇.B. $\quad$ Dergisi, $\quad 37(1), \quad$ 165-192. https://dergipark.org.tr/tr/pub/muiibd/issue/500/4548 (Erişim Tarihi: 28.11.2020).

Çakmak, U. (2016). Güney Kore'nin Ekonomik Kalkınmasının Temel Dinamikleri (19601990). Süleyman Demirel Üniversitesi İktisadi ve İdari Bilimler Fakültesi Dergisi, 21(1), 151-171.

Çarıkçı, E. (1991). Türkiye'de Ekonomik Güçlükler ve Çözüm Yolları. Adım Yayıncılık, Ankara.

Dura, Y. C., Beşer, M. K. ve Acaroğlu, H. (2017). Türkiye'nin İhracata Dayalı Büyümesinin Ekonometrik Analizi. Ege Akademik Bakış Dergisi, 17(2), 295-310. https://dergipark.org.tr/tr/download/article-file/561710 (Erişim Tarihi: 30.11.2020).

England, G. ve Misumi, J. (1986). Work Centrality in Japan and The United States. Journal of Cross-Culturel Psychology, 17.

Ersun, C. ve Sezer Ö. (1991). Güney Kore İhracat Pazar Araştırması. İstanbul Ticaret Odası Ya.No.1991-1, EMA Yayınevi, İstanbul.

Eski, H. (1989). İhracata Yönelik Sanayileşme Stratejisi ve Güney Kore Deneyi. EBSO Yayınları No. 45408, İzmir.

Göçer, İ. ve Hepkarşı, N. (2013). İhracat-Büyüme İlişkisi: Yapısal Kırılmalı Bir Analiz. Siyaset, Ekonomi ve Yönetim Araştırmalar Dergisi, 1(4), 57-87. https://dergipark.org.tr/en/download/article-file/1025296 (Erişim Tarihi: 30.11.2020).

Gulzar, A. ve Li, Z. (2018). Exports-Led Growth or Growth-Led Exports in the Case of China and Pakistan: An Empirical Investigation from the ARDL and Granger Causality Approach. The International Trade Journal, 32(3), 293-314. https://www.tandfonline.com/doi/full/10.1080/08853908.2017.1379449?casa_token=h vn-

e75JVnYAAAAA\%3AMOruKiqkfp1O9LNBv1SstSodHEpNUv_ASAGZftD15Sxb40 OFnt5KC_U80a5NlZwe7OeT_0wBQs4_kQDMvQ (Erişim Tarihi: 23.07.2021). https://doi.org/10.1080/08853908.2017.1379449

Han, E. ve Kaya, A. A. (2006). Kalkınma Ekonomisi Teori ve Politik. Nobel Yayın Dağıtım, Ankara.

Henderson, J., Hulme, D., Phillips, R. ve Kim, E.M. (2002). Economic Governance and Poverty Reduction in South Korea. Korea Report. http://citeseerx.ist.psu.edu/viewdoc/download?doi=10.1.1.198.7202\&rep=rep1\&type= pdf (Erişim Tarihi: 13.06.2021). 
Hiemenz, U. (1999). Growth and Competition in the New Global Economy. OECD Publishing, Paris.

Hong, W. (1987). Export Oriented Growth of Korea. University of Stockholm, Ya. No. 382, Stockholm.

Hong, Y. S. (2010). Private-Public Alliances for Export Development: The Korean Case. CEPAL, Serie Comercio Internacional, No:102, 1-97.

Imaoka, K. O. H. (1990). İki Yönlü (Dual)-Sınai Kalkınma. Çev. Süleyman AKYOL, A.S.O.D., 14(105).

IMF. (2021). World Economic Outlook (World Economic Databases). https://www.imf.org/en/Publications/WEO/Issues/2021/07/27/world-economicoutlook-update-july-2021 (Erişim Tarihi: 09.08.2021).

İGEME. (1990). Güney Kore Ülke Profili. S.1.

Karaosmanoğlu, A. L. (2013). Kore Savaşı'nın Siyasi-Stratejik İkilemleri, Kore Savaşı, Uzak Savaşın Askerleri. Der: Mehmet A. Tuğtan, İstanbul Bilgi Üniversitesi Yayınları, 3052.

Kazgan, G. (1985). Ekonomide Dışa Açık Büyüme. Altın Kitaplar Yayınevi, İstanbul.

Kihwan, K. (1987). The Korean Economy Past Performance Current Reforms and Future Prospects. Seoul.

Kim, L. (1997). Imitation to Innovation: The Dynamics of Korea's Technological Learning. Harvard Business School Press, Boston.

Kim, L. ve C. J. Dahlman. (1992). Technology Policy for Industrialization: An Integrative Framework and Korea's Experience. Research Policy, 21(5), 437-452. https://www.sciencedirect.com/science/article/abs/pii/004873339290004N (Erişim Tarihi: 11.08.2021).

Kim, L. ve Nelson, R. (2000). Technology, Learning, and Innovation: Experiences of Newly Industrializing Economies. Cambridge University Press, Cambridge.

Kim, S. H. (2007). Finance and Growth of the Korean Economy from 1960 to 2004. Seoul Journal of Economics, 20(4), 377-418.

Korea Economic Institute. (2012). Korea's Economy 2012. Volume 28, USA. http://www.keia.org/sites/default/files/publications/kei_koreaseconomy_10-

19 final.pdf (Erişim Tarihi: 13.08.2021).

Korean Intellectual Property Office-KIPO. Statistics-Application by Year (1948-2019). https://www.kipo.go.kr/upload/en/download/Applications.xls (Erişim Tarihi: 12.08.2021).

Korean Statistical Information Services (KOSIS). Statistical Database. https://kosis.kr/eng/statisticsList/statisticsListIndex.do?menuId=M_01_01\&vwcd=MT ETITLE\&parmTabId=M_01_01 (Erişim Tarihi: 09.08.2021).

Krueger, A. O. (1987). The Importance of Economic Policy in Development: Contrasts Between Korea and Turkey. National Bureau of Economic Research Working Paper, No. 2195, 1-56.

KTA. (1992). Major Statistics of Korean Economy. Korean Trade Association (KTA), Seoul. 
Lie, J. (1998). Han Unbound: The Political Economy of South Korea. California: Stanford University Press.

Nahn, A. C. (1998). Kore Tarihi ve Kültürü. Çev.: Ali Rıza Balaman, Ege Üniversitesi Basımevi, İzmir.

Nas, N. P. ve Oktar, S. (1986). Ekonomik Büyümenin Temelleri. Dünya Gazetesi Ekonomi Atlasi-Güney Kore İlavesi, (17 Eylül 1986).

Nguyen, T. H. (2016). Impact of Export on Economic Growth in Vietnam: Empirical Research and Recommendations. International Business and Management, 13(3), 4552. https://core.ac.uk/download/pdf/236300558.pdf (Erişim Tarihi: 02.08.2021).

OECD. Main Science and Technology Indicators. https://www.oecd.org/science/msti.htm (Erişim Tarihi: 13.08.2021).

Öz, S. (2008). Küresel Rekabette Son Aşamaya Ulaşmak: Güney Kore. TUSİAD-Sabancı Üniversitesi Rekabet Forumu, Yayın No: REF 06/2008, İstanbul.

Peterson, M. (2009). A Brief History of Korea. Infobase Publishing.

Rhee, S. -K. (2003). Challenges and Opportunities for Biotechnology Development: the Korean Experiences. in Biotechnology and Development: Challenges and Opportunities for Asia 2004, 57-65, Institute of Southeast Asian Studies, Singapore. https://scholar.google.com/scholar?hl=tr\&as_sdt=0\%2C5\&q=\%E2\%80\%9CChallenge s+and+Opportunities+for+Biotechnology+Development $\% 3 \mathrm{~A}+$ the+Korean++Experien ces\%E2\% 80\%9D\&btnG= (Erişim Tarihi: 12.08.2020).

Sadıklar, C. T. (1989). Kore Dosyası. Ekonomide Ankara, S.28(Kasım), Ankara.

Sengupta, J. K. ve Espana, J. R. (1994). Exports and Economic Growth in Asian NICs: An Econometric Analysis for Korea. Applied Economics, 26, 41-51. https://www.tandfonline.com/doi/abs/10.1080/00036849400000060 (Erişim Tarihi: 01.12.2020). https://doi.org/10.1080/00036849400000060

Seth M. J. (2017). South Korea's Economic Development, 1948-1996. Oxford University Press.

https://oxfordre.com/asianhistory/view/10.1093/acrefore/9780190277727.001.0001/a crefore-9780190277727-e-271?_prclt=8Aofsid3 (Erişim Tarihi: 07.08.2021). https://doi.org/10.1093/acrefore/9780190277727.013.271

Savada A. M. ve Shaw W. (editors) (1990). South Korea: A Country Study. Washington: GPO for the Library of Congress, http://countrystudies.us/south-korea/47.htm (Erişim Tarihi: 06.08.2021).

Shan, J. ve Sun, F. (1998). On The Export-Led Growth Hypothesis: The Econometric Evidence from China. Applied Economics, 30(8), 1055-1065. https://www.tandfonline.com/doi/pdf/10.1080/000368498325228 (Erişim Tarihi: 30.11.2020). https://doi.org/10.1080/000368498325228

Sharma, A. ve Panagiotidis, T. (2005). An Analysis of Exports and Growth in India: Cointegration and Causality Evidence (1971-2001). Review of Development Economics, 9(2), 232-248. https://www.researchgate.net/publication/4781686_An_Analysis_of_Exports_and_Gr owth_in_India_Cointegration_and_Causality_Evidence_1971-2001 (Erişim Tarihi: 01.12.2020). DOI: 10.1111/j.1467-9361.2005.00273.x 
Shutt, H. (2004). Kapitalizmle Derdim Var!. Çev. Nesrin Sungur ve Ahmet Çakmak, Kitap Yayınevi, İstanbul.

Sönmez, A. (2001). Doğu Asya "Mucizesi" ve Bunalımı: Türkiye İçin Dersler. Bilgi Üniversitesi Yayınları, İstanbul.

Sridharan, E. (1996). The Political Economy of Industrial Promotion: Indian, Brazilian, and Korean Electronics in Comparative Perspective 1969-1994. Greenwood Publishing Group, Westport.

Suh, J. (2000). Korea's Innovation Systems: Challenges and New Policy Agenda. The United Nations University/INTECH Discussion Paper Series. https://citeseerx.ist.psu.edu/viewdoc/download?doi=10.1.1.26.1544\&rep=rep1\&type= pdf (Erişim Tarihi: 10.08.2021).

Sung-Shen, N., Biswas, B. ve Tribedy, G. (1990). Causality between Exports and Economic Growth: An Empirical Study. Journal of Economic Development, 15(1), 47-61. http://jed.or.kr/full-text/15-1/3.pdf (Erişim Tarihi: 05.08.2021).

Taban, S. ve Aktar, I. (2008). An Empirical Examination of the Export-Led Growth Hypothesis in Turkey. Journal of Yasar University, 3(11), 1535-1551. https://dergipark.org.tr/tr/pub/jyasar/issue/19123/202929 (Erişim Tarihi: 30.11.2020).

TASAM. (2007). Güney Kore Nükleer Teknoloji İnceleme Gezisi. Stratejik Rapor No:18, Nisan 2007, Türk Asya Stratejik Araştırmalar Merkezi (TASAM) Yayınları, İstanbul.

TEIU. (1992). South Korea Country Profile 1992-93. The Economist Intelligence Unit (TEIU), Seoul.

Teodora, M. I. ve Marinela, S. R. (2011). An Investigation of Longrun Relationship Between Economic Growth, Investment and Export in Romania. Annals of Faculty of Economics, $1(1)$, 316-321. https://www.researchgate.net/publication/227462762_AN_INVESTIGATION_OF_L ONGRUN_RELATIONSHIP_BETWEEN_ECONOMIC_GROWTH_INVESTMENT AND_EXPORT_IN_ROMANIA (Erişim Tarihi: 30.11.2020).

TMMOB. (2007). Ülke Örnekleri ile Kalkınma ve Sanayileşme Modelleri. TMMOB Sanayi $\begin{array}{llll}\text { Kongresi } & 2007 & \text { Oda } & \text { Raporu, }\end{array}$ https://www.mmo.org.tr/sites/default/files/403675579f61145_ek_0.pdf (Erişim Tarihi: 07.08.2021).

TURKTRADE. (1988). Güney Kore'de İhracat Teşvikleri. Durum Dergisi, S.13.

TÜSİAD. (1978). Güney Kore'de Yabancı Sermaye Teşvikleri. Görüş Dergisi (Eylül), 6(9), İstanbul.

TÜSİAD. (1985). Güney Kore'de Teşvik Tedbirleri. Görüş Dergisi (Eylül), 13(9), İstanbul.

TÜSİAD. (1986). Güney Kore'de Son Durum. Görüş Dergisi (Aralık), 14(12), İstanbul.

Takım, A. (2010). Türkiye'de GSYİH ile İhracat Arasındaki İlişki: Granger Nedensellik Testi. Atatürk Üniversitesi Sosyal Bilimler Enstitüsü Dergisi, 14(2), 315-330. https://dergipark.org.tr/en/pub/ataunisosbil/issue/2826/38224 (Erişim Tarihi: 01.08.2021).

Ungson, G. R., Steers, R. M. ve Park, S. H. (1997). Korean Enterprise: The Quest for Globalization. Harvard Business School Press, Boston, Massachusetts. 
Vogel, E. F. (1991). The Four Little Dragons: The Spread of Industrialization in East Asia. Harvard University Press, Cambridge, Massachusetts.

Weber, M. (1985). Protestan Ahlakı ve Kapitalizmin Ruhu. Hil Yayınları, İstanbul.

World Bank. Databank (World Development Indicators). https://databank.worldbank.org/source/world-development-indicators (Erişim Tarihi: 09.08.2021).

World Bank. (2006). Korea as a Knowledge Economy: Evolutionary Process and Lessons Learned. Ed. Suh, J. ve Chen, D. H. C. The World Bank, Washington, DC. https://books.google.com.tr/books?hl=tr\&lr=\&id=2V76oBba-

OUC\&oi=fnd\&pg=PR3\&dq=\%E2\%80\%9CKorea $+\mathrm{as}+\mathrm{a}+$ Knowledge + Economy $:+\mathrm{Evo}$ lutionary+Process+and+Lessons+Learned $\%$ E2\% 80\%9D\&ots=aaOz55Eqvd\&sig=TM

iZr4iyjF637onKGffddZcw5g\&redir_esc=y\#v=onepage\&q=\%E2\%80\%9CKorea $\% 20$ as $\% 20 \mathrm{a} \% 20 \mathrm{Knnowledge} \% 20$ Economy $\% 3 \mathrm{~A} \% 20$ Evolutionary $\% 20 \mathrm{Process} \% 20$ and $\% 20$ Lessons\%20Learned\%E2\%80\%9D\&f=false (Erişim Tarihi: 11.08.2021).

Yim, D. S. (2004). Korea's National Innovation System and the Science and Technology Policy. Global S\&T Center, Science and Technology Policy Institute (STEPI), Seoul, Korea.

http://www.unesco.org/new/fileadmin/MULTIMEDIA/HQ/SC/pdf/WA_korea.pdf (Erişim Tarihi: 08.08.2021).

Yoo, I. (2008). Korea's Economic Developments: Lessons and Suggestions for Developing Countries. Korean Social Science Journal, XXXV No.1, 31-63. 